Louisiana State University

LSU Digital Commons

Faculty Publications

Department of Chemistry

$7-1-2000$

\title{
Theoretical studies of the reactivity of cyclopentadienyl nitrosyl alkyl species of molybdenum and tungsten
}

\author{
Rinaldo Poli \\ Universite de Bourgogne \\ Kevin M. Smith \\ Universite de Bourgogne
}

Follow this and additional works at: https://digitalcommons.Isu.edu/chemistry_pubs

\section{Recommended Citation}

Poli, R., \& Smith, K. (2000). Theoretical studies of the reactivity of cyclopentadienyl nitrosyl alkyl species of molybdenum and tungsten. Organometallics, 19 (15), 2858-2867. https://doi.org/10.1021/om000088p

This Article is brought to you for free and open access by the Department of Chemistry at LSU Digital Commons. It has been accepted for inclusion in Faculty Publications by an authorized administrator of LSU Digital Commons. For more information, please contact ir@lsu.edu. 


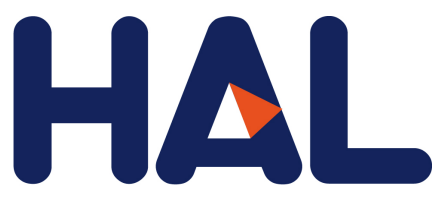

archives-ouvertes

\section{Theoretical Studies of the Reactivity of Cyclopentadienyl Nitrosyl Alkyl Species of Molybdenum and Tungsten}

Rinaldo Poli, Kevin Smith

\section{To cite this version:}

Rinaldo Poli, Kevin Smith. Theoretical Studies of the Reactivity of Cyclopentadienyl Nitrosyl Alkyl Species of Molybdenum and Tungsten. Organometallics, American Chemical Society, 2000, 19 (15), pp.2858-2867. 10.1021/om000088p . hal-03295970

\section{HAL Id: hal-03295970 \\ https://hal.archives-ouvertes.fr/hal-03295970}

Submitted on 28 Jul 2021

HAL is a multi-disciplinary open access archive for the deposit and dissemination of scientific research documents, whether they are published or not. The documents may come from teaching and research institutions in France or abroad, or from public or private research centers.
L'archive ouverte pluridisciplinaire HAL, est destinée au dépôt et à la diffusion de documents scientifiques de niveau recherche, publiés ou non, émanant des établissements d'enseignement et de recherche français ou étrangers, des laboratoires publics ou privés. 


\title{
Theoretical Studies of the Reactivity of Cyclopentadienyl Nitrosyl Alkyl Species of Molybdenum and Tungsten
}

\author{
Rinaldo Poli and Kevin M. Smith* \\ Laboratoire de Synthèse et d'Electrosynthèse Organométallique, \\ Université de Bourgogne, Faculté de Sciences "Gabriel", 6 Boulevard Gabriel, \\ 21100 Dijon, France.
}




\begin{abstract}
The reactivity differences observed experimentally for $\mathrm{Cp} * \mathrm{~W}(\mathrm{NO})\left(\mathrm{CH}_{2} \mathrm{CMe}_{3}\right)_{2}$ and $\mathrm{CpMo}(\mathrm{NO})\left(\mathrm{CH}_{2} \mathrm{CMe}_{3}\right)_{2}$ are investigated using density functional theory (DFT) techniques. The reactions of the $\mathrm{CpW}(\mathrm{NO})\left(\mathrm{CH}_{2}\right)$ model complex with $\mathrm{NH}_{3}$ and $\mathrm{CH}_{4}$ are more exothermic and have lower activation barriers than the corresponding processes for $\mathrm{CpMo}(\mathrm{NO})\left(\mathrm{CH}_{2}\right)$. The $\eta^{2}-\mathrm{C}, \mathrm{H}$ methane complex $\mathrm{CpM}(\mathrm{NO})\left(\mathrm{CH}_{2}\right)\left(\mathrm{CH}_{4}\right)(\mathrm{M}=\mathrm{Mo}, \mathrm{W})$ can undergo two competitive processes: $\mathrm{C}-\mathrm{H}$ activation to afford $\mathrm{CpM}(\mathrm{NO})\left(\mathrm{CH}_{3}\right)_{2}$ or loss of methane. The relative barrier heights are almost identical for $\mathrm{M}=\mathrm{W}$, whereas the formation of $\mathrm{CpM}(\mathrm{NO})\left(\mathrm{CH}_{3}\right)_{2}$ is significantly disfavored for $\mathrm{M}=$ Mo. The activation of $\mathrm{C}-\mathrm{H}$ and $\mathrm{N}-\mathrm{H}$ bonds proceeds via a direct, metal-assisted 1,2 addition across the $\mathrm{M}=\mathrm{CH}_{2}$ bond without a distinct carbene-hydride intermediate. The relative stability order of the products can be rationalized in part through metal-ligand $\pi$-bonding considerations. The relative orbital energies, which are consistently lower for Mo than for $\mathrm{W}$, can be used to rationalize various reactivity differences observed experimentally for the $\mathrm{CpM}(\mathrm{NO})(\text { alkyl })_{2}$ species, including the selective coordination of small molecules. The absence of sufficient steric bulk in the model complexes likely contributes to the overestimation of the calculated activation energies, and the discrepancy between some of the calculated and experimental structural parameters.
\end{abstract}




\section{Introduction}

The activation of $\mathrm{C}-\mathrm{H}$ and $\mathrm{N}-\mathrm{H}$ bonds by transition metal complexes constitutes a critical step in a variety of stoichiometric and catalytic reactions. ${ }^{1}$ Many investigations have been undertaken in order to understand this fundamental process, with theoretical studies $^{2}$ proving particularly useful when the key intermediates are too fleeting to be observed by standard spectroscopic methods. ${ }^{3}$ The studies of stoichiometric alkane $\mathrm{C}-\mathrm{H}$ activation by non- $\mathrm{d}^{0}$ complexes have largely focused on late transition metals, especially $\mathrm{Rh}$ and Ir.4,5 Recently, however, W-based systems capable of alkane $\mathrm{C}-\mathrm{H}$ activation have been generated via thermolytic elimination of $\mathrm{SiMe}_{4}$ or $\mathrm{CMe}_{4}$ from $\mathrm{Cp} * \mathrm{~W}(\mathrm{NO})\left(\mathrm{CH}_{2} \mathrm{CMe}_{3}\right)_{2}$ or $\mathrm{Cp} * \mathrm{~W}(\mathrm{NO})\left(\mathrm{CH}_{2} \mathrm{SiMe}_{3}\right)\left(\mathrm{CPh}=\mathrm{CH}_{2}\right)$, respectively. 6,7

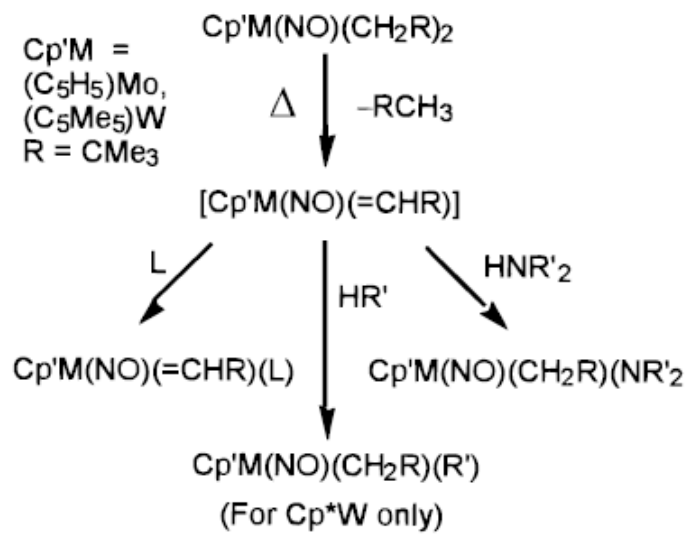

Scheme 1

Scheme 1 illustrates the $\alpha$-hydrogen abstraction reaction for both $\mathrm{Cp}^{*} \mathrm{~W}(\mathrm{NO})$ $\left(\mathrm{CH}_{2} \mathrm{CMe}_{3}\right)_{2}$ and $\mathrm{CpMo}(\mathrm{NO})\left(\mathrm{CH}_{2} \mathrm{CMe}_{3}\right)_{2}$, and the characteristic reactivity of the resulting transient alkylidene species. $6,8,9$ While the thermal elimination of $\mathrm{CMe}_{4}$ requires heating to $70^{\circ} \mathrm{C}$ for the $\mathrm{Cp} * \mathrm{~W}$ bis(neopentyl) species, the same process occurs readily at $25^{\circ} \mathrm{C}$ for $\mathrm{CpMo}(\mathrm{NO})\left(\mathrm{CH}_{2} \mathrm{CMe}_{3}\right)_{2}$. In the presence of a trapping ligand $\mathrm{L}$ (e.g. phosphines, pyridine), the alkylidene can be isolated as a $\mathrm{Cp} * \mathrm{~W}(\mathrm{NO})\left(\mathrm{CHCMe}_{3}\right)(\mathrm{L})$ or $\mathrm{CpMo}(\mathrm{NO})\left(\mathrm{CHCMe}_{3}\right)(\mathrm{L})$ adduct. ${ }^{6,8}$ Both $\mathrm{Cp} * \mathrm{~W}$ and $\mathrm{CpMo}$ systems react with primary or secondary amines to give alkyl amido compounds.9,10 However, while 
$\mathrm{Cp} * \mathrm{~W}(\mathrm{NO})\left(\mathrm{CHCMe}_{3}\right)$ activates even normally unreactive $\mathrm{C}-\mathrm{H}$ bonds in substrates such as cyclohexane, $\mathrm{CpMo}(\mathrm{NO})\left(\mathrm{CHCMe}_{3}\right)$ does not display any $\mathrm{C}-\mathrm{H}$ activation with alkanes or arenes. ${ }^{11}$ Note that $\mathrm{CpW}(\mathrm{NO})\left(\mathrm{CH}_{2} \mathrm{CMe}_{3}\right)_{2}$ is also capable of solvent $\mathrm{C}-\mathrm{H}$ activation upon thermolysis, ${ }^{10}$ confirming that the reactivity differences between the $\mathrm{W}$ and Mo systems is not simply due to variations in the ancillary ligands. ${ }^{12}$

(a)
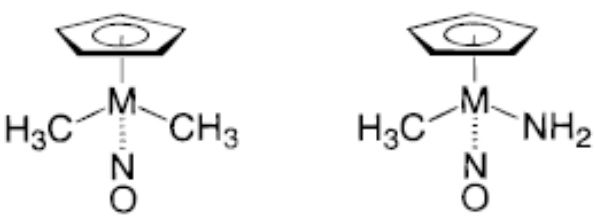

(b)
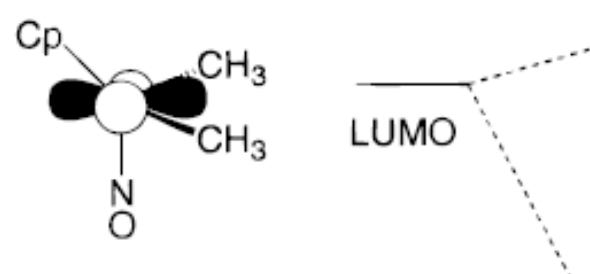<smiles>[CH]1C[CH+]CC1</smiles>
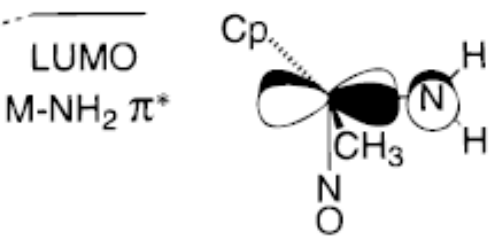

$\mathrm{M}-\mathrm{NO} \pi$

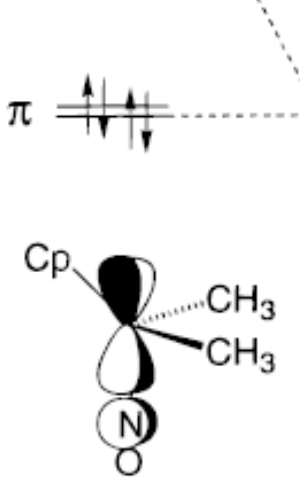

$\mathrm{M}-\mathrm{NO} \pi$
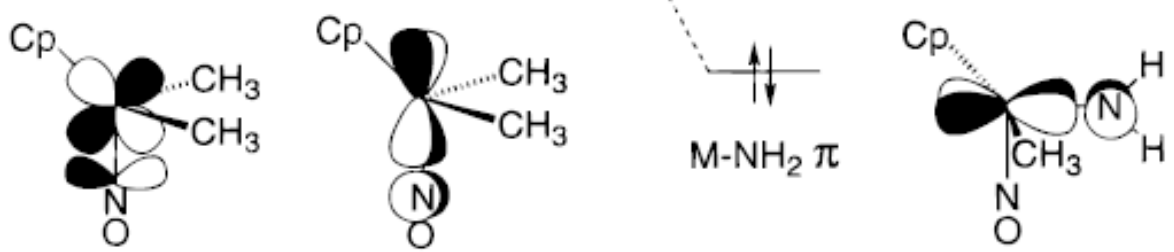

Figure 1. Qualitative diagram of frontier molecular orbitals and energies for (a) $\mathrm{CpM}(\mathrm{NO})\left(\mathrm{CH}_{3}\right)_{2}$ and (b) $\mathrm{CpM}(\mathrm{NO})\left(\mathrm{CH}_{3}\right)\left(\mathrm{NH}_{2}\right)$.

Previous theoretical studies of $\mathrm{CpW}(\mathrm{NO})$ - and $\mathrm{CpMo}(\mathrm{NO})$-containing compounds have been performed using Extended Hückel and Fenske-Hall molecular orbital calculations. ${ }^{13-16}$ Many of the distinctive properties of $\mathrm{Cp} \mathrm{p}^{\prime} \mathrm{M}(\mathrm{NO}) \mathrm{X}_{2}$ complexes $\left(\mathrm{Cp}^{\prime}=\right.$ $\mathrm{Cp}$ or $\mathrm{Cp}^{*} ; \mathrm{X}=$ alkyl, amido, or other monoanionic ligand) ${ }^{17}$ can be attributed to $\pi$ bonding effects on the frontier orbital energies, as illustrated schematically in Figure 1. 
In $\mathrm{CpM}(\mathrm{NO})\left(\mathrm{CH}_{3}\right)_{2}$, two of the three metal $\mathrm{d} \pi$ orbitals are engaged in $\pi$ bonding to the nitrosyl ligand, and are much lower in energy than the metal-centered, non-bonding orbital perpendicular to the M-NO axis. This splitting pattern is responsible for the stability of these diamagnetic 16 electron (16e) bis(alkyl) species, since their electronic unsaturation does not result in any reduction of metal-ligand binding. ${ }^{14,15}$ The relatively low energy of the LUMO renders these complexes prone to coordinate small molecules which may then proceed to react with the metal-alkyl bonds. ${ }^{18}$

Replacing one $\mathrm{CH}_{3}$ group with an $\mathrm{NH}_{2}$ ligand allows the empty d orbital on the metal center to form a $\pi$ bond with the filled $\mathrm{p}$ orbital on the amido $\mathrm{N}$ atom, as shown in Figure 1(b). In order to maintain this $\pi$ interaction, the planar $\mathrm{M}-\mathrm{NH}_{2}$ group must remain aligned with the $\mathrm{M}-\mathrm{NO}$ axis, resulting in pronounced energetic barriers to ligand rotation. ${ }^{13,16}$ This preferred orientation has been observed experimentally in X-ray crystallographic studies of amido, thiolato, alkoxo, and alkylidene $\mathrm{CpM}(\mathrm{NO})$ complexes of $\mathrm{Cr}$, Mo and W. ${ }^{19}$ The $\mathrm{Cp} \mathrm{p}^{\prime} \mathrm{M}(\mathrm{NO}) \mathrm{X}_{2}$ compounds which possess these $\mathrm{M}-\mathrm{X} \pi$-bonding interactions are effectively electronically saturated, since the higher LUMO energy renders the metal center less susceptible to nucleophilic attack.

In this paper, we use density functional theory (DFT) to investigate the reactivity of $\mathrm{Cp}^{\prime} \mathrm{M}(\mathrm{NO})\left(\mathrm{CH}_{2} \mathrm{R}\right)_{2}$ complexes of $\mathrm{Mo}$ and $\mathrm{W}$. The activation of $\mathrm{C}-\mathrm{H}$ and $\mathrm{N}-\mathrm{H}$ bonds by transient alkylidene species is addressed in the initial sections of paper, followed by a discussion of adduct formation. Simplified models of both the substrates and organometallic reactants are employed (i.e. $\mathrm{CH}_{4}, \mathrm{NH}_{3}$, and $\mathrm{CpM}(\mathrm{NO})\left(\mathrm{CH}_{3}\right)_{2}$ ) in order to minimize computational expense. While this approach neglects steric effects operating in the actual compounds, the electronic effects that are highlighted provide a basis for a qualitative analysis of these systems. In particular, many key features in the reactivity of $\mathrm{Cp}$ 'M(NO) $\left(\mathrm{CH}_{2} \mathrm{R}\right)_{2}$ complexes are shown to be rationalized by examining the bonding character and relative energies of the frontier molecular orbitals, especially when accounting for the divergent reactivity modes exhibited by the Mo and W systems. 


\section{Results and Discussion}

C-H Bond Activation. The relative energies of the intermediates, transition states and products of the reactions of $\mathrm{CpM}(\mathrm{NO})\left(\mathrm{CH}_{2}\right)$ with $\mathrm{CH}_{4}$ and $\mathrm{NH}_{3}$ are shown in Figure 2. All geometries were optimized without symmetry constraints in the singlet spin state, and the energies (including zero-point energy corrections) are calculated relative to $\mathrm{CpM}(\mathrm{NO})\left(\mathrm{CH}_{2}\right)$ plus free $\mathrm{CH}_{4}$ or $\mathrm{NH}_{3}$.

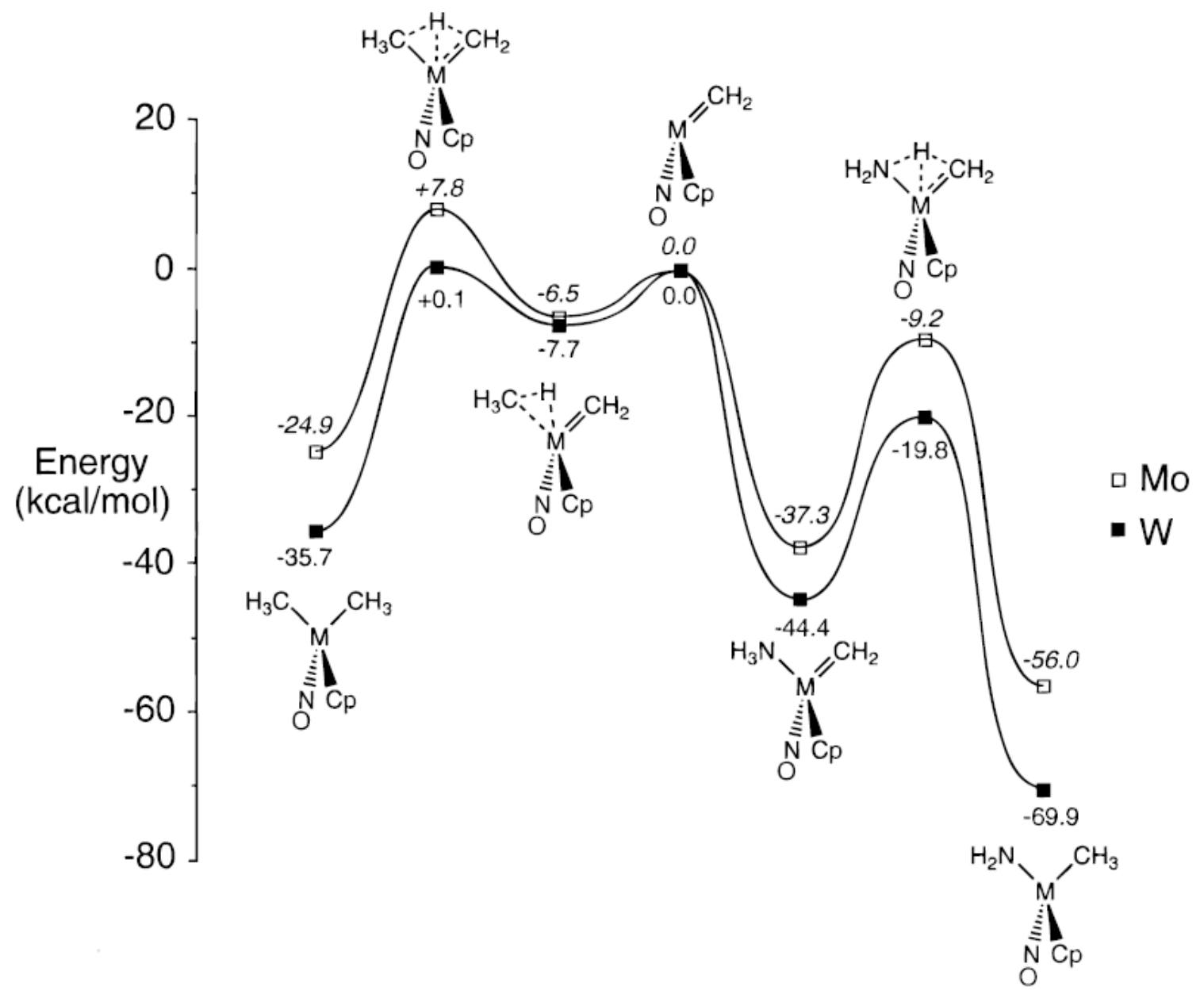

Figure 2. Potential energy profiles of the reaction of $\mathrm{CpM}(\mathrm{NO})\left(\mathrm{CH}_{2}\right)$ with $\mathrm{CH}_{4}$ and $\mathrm{NH}_{3}$.

$\mathbf{C p M}(\mathrm{NO})\left(\mathbf{C H}_{3}\right)_{2}$. The electronic structures of $\mathrm{CpMo}(\mathrm{NO})\left(\mathrm{CH}_{3}\right)_{2}$ and $\mathrm{CpW}(\mathrm{NO})\left(\mathrm{CH}_{3}\right)_{2}$ have previously been examined by Bursten and co-workers using the Fenske-Hall 
molecular orbital method. ${ }^{14,15}$ Figure 3(a) shows the DFT-optimized geometries of the $\mathrm{CpM}(\mathrm{NO})\left(\mathrm{CH}_{3}\right)_{2}$ compounds. While the bis(methyl) structures are relatively symmetric with a non-imposed, approximate $\mathrm{C}_{\mathrm{s}}$ mirror plane, they are strongly distorted from the typical $\mathrm{CpML}_{3}$ structure. The angle between the methyl groups is over $20^{\circ}$ larger than the ideal $90^{\circ}$, and the $\mathrm{CP}-\mathrm{M}-\mathrm{CH}_{3}$ angle $(\mathrm{CP}=$ midpoint of the $\mathrm{Cp}$ ring $)$ is smaller than the ideal $125.26^{\circ}$, with the deformation being slightly more pronounced for the Mo complex than for $\mathrm{W}$.

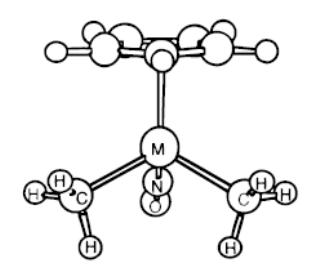

(a)

$\begin{array}{ccc} & \text { W } & \text { Mo } \\ \text { M- } \mathrm{CH}_{3} & 2.153 & 2.140\end{array}$

$\begin{array}{lll}\mathrm{M}-\mathrm{N} & 1.770 \quad 1.775\end{array}$

C-M-C $\quad 110.3 \quad 114.7$

$\begin{array}{lll}C-M-N O & 95.3 & 94.6\end{array}$

$\begin{array}{lrr}\text { C-M-NO } & 95.3 & 94.6 \\ \text { CP-M-C } & 113.2 & 112.5 \\ \text { CP-M-N } & 127.3 & 126.3\end{array}$

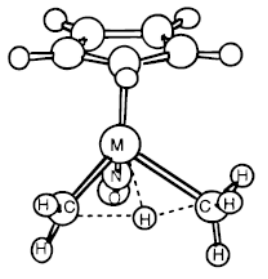

(b)

$\begin{array}{ccc} & \text { W } & \text { Mo } \\ \text { M- } \mathrm{CH}_{3} & 1.971 & 1.971\end{array}$ $\begin{array}{lll}\mathrm{M}-\mathrm{CH}_{2} & 2.356 & 2.354\end{array}$

$\begin{array}{lll}\mathrm{M}-\mathrm{H} & 1.812 & 1.804\end{array}$

$\mathrm{H}_{2} \mathrm{C}-\mathrm{H} \quad 1.723 \quad 1.638$

$\mathrm{H}_{3} \mathrm{C}-\mathrm{H} \quad 1.453 \quad 1.494$

C-M-C $\quad 92.0 \quad 90.6$

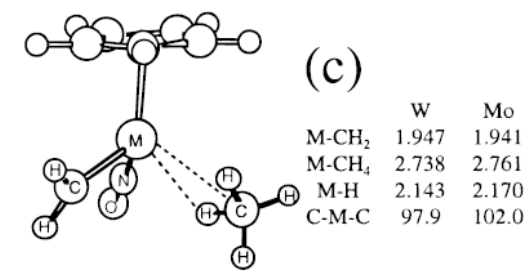

Figure 3. Optimized geometries of (a) $\mathrm{CpM}(\mathrm{NO})\left(\mathrm{CH}_{3}\right)_{2}$, (b) $\mathrm{CpM}(\mathrm{NO})\left(\mathrm{H}_{3} \mathrm{C} \cdots \mathrm{H} \cdots \mathrm{CH}_{2}\right)$, and (c) $\mathrm{CpM}(\mathrm{NO})\left(\mathrm{CH}_{2}\right)\left(\mathrm{CH}_{4}\right)$.

As described in the Introduction, the stability of the 16e singlet bis(methyl) complexes has been attributed to the orbital splitting resulting from the $\mathrm{M}-\mathrm{NO} \pi$-bonding interaction. ${ }^{14,15}$ However, additional stabilization of the $\mathrm{CpM}(\mathrm{NO})\left(\mathrm{CH}_{3}\right)_{2}$ complex is achieved by distorting the regular $\mathrm{CpML}_{3}$ geometry displayed in Figure 4(a). Increasing the $\mathrm{H}_{3} \mathrm{C}-\mathrm{M}-\mathrm{CH}_{3}$ angle leads to the rehybridization and destabilization of the LUMO as shown in Figure 4(b), lowering the total energy of the molecule by the corresponding 
stabilization of occupied orbital(s). ${ }^{20}$ This type of geometric distortion has been analyzed for other $16 \mathrm{e} \mathrm{CpML}_{2} \mathrm{~d}^{6}$ and $\mathrm{CpML}_{3} \mathrm{~d}^{4}$ compounds. ${ }^{21-25}$ The large $\mathrm{C}-\mathrm{M}-\mathrm{C}$ angles had also previously been noted for $\mathrm{CpM}(\mathrm{NO}) \mathrm{R}_{2}$ and $\mathrm{Cp} * \mathrm{M}(\mathrm{NO}) \mathrm{R}_{2}$ complexes $(\mathrm{R}$ $=$ alkyl or aryl) based on X-ray crystallographic studies, ${ }^{18}$ but the comparative bulk of the R groups employed experimentally obscured the electronic origin of the deformation.

(a)

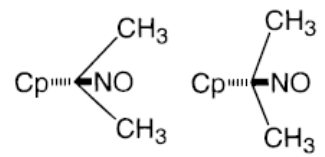

(b)
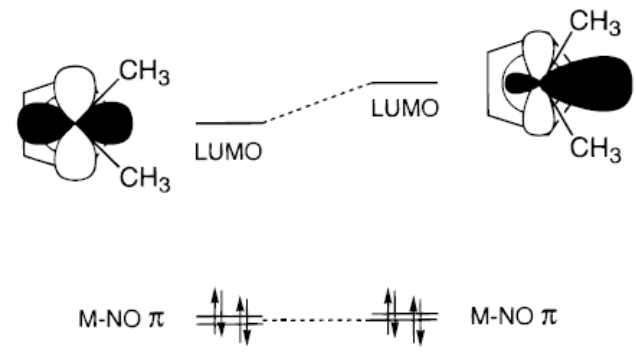

Figure 4. Qualitative diagram of frontier $\mathrm{MO}$ energies for (a) $\mathrm{CpM}(\mathrm{NO})\left(\mathrm{CH}_{3}\right)_{2}$ in ideal $\mathrm{CpML}_{3}$ geometry and (b) $\mathrm{CpM}(\mathrm{NO})\left(\mathrm{CH}_{3}\right)_{2}$ with increased $\mathrm{H}_{3} \mathrm{C}-\mathrm{M}-\mathrm{CH}_{3}$ angle. Pictorial representation of LUMO for (a) and (b) in $\mathrm{M}\left(\mathrm{CH}_{3}\right)_{2}$ plane, as viewed down the M-NO axis.

The $\mathrm{CpM}(\mathrm{NO})\left(\mathrm{CH}_{3}\right)_{2}$ structures also display $\alpha$ agostic interactions between one $\mathrm{H}$ on each methyl group and the metal-based LUMO shown in Figure 4(b). One H-C-M angle for each $\mathrm{CH}_{3}$ ligand (101.3 and $103.7^{\circ}$ for Mo and $\mathrm{W}$, respectively) is distinctly smaller than for the others, which range from 113.1 to $114.9^{\circ}$ in both structures. The possibility of some $\alpha \mathrm{C}-\mathrm{H} \rightarrow \mathrm{W}$ interaction was invoked in the initial report of $\mathrm{CpW}(\mathrm{NO})\left(\mathrm{CH}_{2} \mathrm{CMe}_{3}\right)_{2}$ based on coupling constants obtained via ${ }^{13} \mathrm{C}$-gated decoupled NMR spectroscopy. It was also noted that "these $\mathrm{C}-\mathrm{H} \rightarrow \mathrm{M}$ links, if they do exist, do not apparently affect the characteristic chemistry of these compounds". 26 Similar double $\alpha$ agostic interactions have been proposed in $\mathrm{d}^{0}$ bis(alkyl) compounds on the basis of X-ray 
crystallographic $^{27}$ and NMR data. ${ }^{28}$ In light of the interpretation of Schrock and coworkers of the large ${ }^{4} J_{\mathrm{HH}}$ coupling in $\mathrm{CpW}(\mathrm{CR})\left(\mathrm{CH}_{2} \mathrm{CR}\right)\left(\mathrm{CH}_{2} \mathrm{R}\right.$ ') complexes in terms of alkyl group orientation and $\alpha$ agostic interactions, ${ }^{28}$ it now seems likely that the same considerations can be applied to $\mathrm{Cp} * \mathrm{M}(\mathrm{NO})\left(\mathrm{CH}_{2} \mathrm{R}\right)\left(\mathrm{CH}_{2} \mathrm{R}^{\prime}\right)$ and $\mathrm{CpW}(\mathrm{NO})\left(\mathrm{CH}_{2} \mathrm{R}\right)$ $\left(\mathrm{CH}_{2} \mathrm{R}^{\prime}\right)$ compounds which were reported to display similar ${ }^{4} J_{\mathrm{HH}}$ couplings. ${ }^{29,30}$

The tungsten bis(methyl) compound is calculated to be much more thermodynamically stable with respect to $\mathrm{CpM}(\mathrm{NO})\left(\mathrm{CH}_{2}\right)$ and free $\mathrm{CH}_{4}$ than the corresponding molybdenum complex, by 35.7 and $24.9 \mathrm{kcal} / \mathrm{mol}$, respectively.

$\mathbf{C p M}(\mathbf{N O})\left(\mathbf{H}_{2} \mathbf{C} \cdots \mathbf{H} \cdots \mathbf{C H}_{3}\right)$. The optimized geometry for the $\mathrm{C}-\mathrm{H}$ activation transition state is illustrated in Figure 3(b). Along the reaction coordinate from $\mathrm{CpM}(\mathrm{NO})\left(\mathrm{CH}_{3}\right)_{2}$ to $\mathrm{CpM}(\mathrm{NO})\left(\mathrm{CH}_{2}\right)\left(\mathrm{CH}_{4}\right)$, this is a "late" transition state. The $\mathrm{C}-\mathrm{M}-\mathrm{C}$ angle has reduced to close to $90^{\circ}$ from the obtuse angle in $\mathrm{CpM}(\mathrm{NO})\left(\mathrm{CH}_{3}\right)_{2}$ and the hydrogen atom being transferred is more than halfway to the "H-acceptor" carbon. More importantly, the "Hdonor" carbon is essentially already an alkylidene ligand in the transition state: the $\mathrm{H}_{2} \mathrm{CM}$ unit is planar and aligned with the $\mathrm{M}-\mathrm{NO}$ axis, and the $\mathrm{M}-\mathrm{CH}_{2}$ bond length is 0.169 and $0.182 \AA$ shorter for $\mathrm{M}=$ Mo and $\mathrm{W}$, respectively, than in $\mathrm{CpM}(\mathrm{NO})\left(\mathrm{CH}_{3}\right)_{2}$.

Frequency calculations confirm that the structure in Figure 3(b) is indeed a transition state. Attempts to locate a distinct $\mathrm{CpM}(\mathrm{NO})\left(\mathrm{CH}_{2}\right)\left(\mathrm{CH}_{3}\right) \mathrm{H}$ intermediate for either metal were unsuccessful. Other important geometric features of the transition state include the relatively close contact between the transferred $\mathrm{H}$ atom and the metal $(\mathrm{M} \cdots \mathrm{H}$ $=1.812$ and $1.804 \AA$ for $\mathrm{W}$ and Mo, respectively), and the near-planarity of the $\mathrm{H}$ atom in transit, the two $\mathrm{C}$ atoms and the metal atom. Note that this transition state corresponds to a $\mathrm{C}-\mathrm{H}$ activation of methane when going to $\mathrm{CpM}(\mathrm{NO})\left(\mathrm{CH}_{3}\right)_{2}$ from $\mathrm{CpM}(\mathrm{NO})\left(\mathrm{CH}_{2}\right)\left(\mathrm{CH}_{4}\right)$ via a 1,2- $\mathrm{CH}$ addition across the $\mathrm{M}=\mathrm{CH}_{2}$ double bond.

This transition state lies at almost the same energy as the singlet 16e alkylidene for tungsten, but the molybdenum species is $7.8 \mathrm{kcal} / \mathrm{mol}$ higher in energy than $\mathrm{CpMo}(\mathrm{NO})\left(\mathrm{CH}_{2}\right)$ plus free $\mathrm{CH}_{4}$. Even with the relatively high energy of the Mo 
transition state, the overall energy barrier to methane elimination is larger for $\mathrm{CpW}(\mathrm{NO})\left(\mathrm{CH}_{3}\right)_{2}$ than for $\mathrm{CpMo}(\mathrm{NO})\left(\mathrm{CH}_{3}\right)_{2}$ (35.8 and $32.7 \mathrm{kcal} / \mathrm{mol}$, respectively), qualitatively consistent with the experimentally observed difference in thermal stability of the $\mathrm{W}$ and Mo bis(neopentyl) compounds. The degree of order in the transition state geometry is also in agreement with the large, negative $\Delta \mathrm{S}^{\ddagger}$ values observed in kinetic measurements of the conversion of $\mathrm{CpMo}(\mathrm{NO})\left(\mathrm{CD}_{2} \mathrm{CMe}_{3}\right)_{2}$ to $\mathrm{CpMo}(\mathrm{NO})\left(\mathrm{CDCMe}_{3}\right)$ and $\mathrm{CD}_{3} \mathrm{CMe}_{3} .{ }^{9}$

$\mathbf{C p M}(\mathbf{N O})\left(\mathbf{C H}_{2}\right)\left(\mathbf{C H}_{4}\right)$. Transition metal alkane complexes ${ }^{31}$ are often invoked as intermediates in $\mathrm{C}-\mathrm{H}$ bond activation reactions by unsaturated organometallic complexes. 32 As illustrated in Figure 3(c), methane adducts of $\mathrm{CpM}(\mathrm{NO})\left(\mathrm{CH}_{2}\right)$ were located as distinct intermediates for both Mo and W. The methane ligand is coordinated in an $\eta^{2}-\mathrm{C}, \mathrm{H}$ mode, with the next closest $\mathrm{M} \cdots \mathrm{H}$ distance being $>0.4 \AA$ longer. The most distinctive features of the methane group are the slightly elongated $\mathrm{C}-\mathrm{H}$ length for the bound hydrogen (1.119 and $1.120 \AA$ for Mo and $\mathrm{W}$, respectively, with the remaining methane $\mathrm{C}-\mathrm{H}$ bonds all less than $1.10 \AA$ ), and an increased $\mathrm{H}-\mathrm{C}-\mathrm{H}$ angle between the two hydrogens closest to the metal center $\left(116.5^{\circ}\right.$ and $117.2^{\circ}$ for Mo and W, respectively). ${ }^{33}$

The relative barrier heights from the $\mathrm{CpM}(\mathrm{NO})\left(\mathrm{CH}_{2}\right)\left(\mathrm{CH}_{4}\right)$ complexes to either the $\mathrm{C}-\mathrm{H}$ activation transition state or the 16 e alkylidene plus free $\mathrm{CH}_{4}$ is strongly metal dependent. Both competing processes have almost identical energetic barriers for $\mathrm{W}$. For Mo, however, the barrier for $\mathrm{C}-\mathrm{H}$ activation from the alkane complex is considerably higher $(14.3 \mathrm{kcal} / \mathrm{mol})$ than loss of $\mathrm{CH}_{4}(6.5 \mathrm{kcal} / \mathrm{mol})$. This variation in relative energies has important implications for the reactivity differences observed experimentally for the Mo and $\mathrm{W}$ systems and, as discussed in the final section of this paper, can be correlated with the $\Delta \mathrm{E}_{S T}$ values calculated for the $\mathrm{CpM}(\mathrm{NO})\left(\mathrm{CH}_{2}\right)$ species. When $\mathrm{CpMo}(\mathrm{NO})\left(\mathrm{CH}_{2} \mathrm{CMe}_{3}\right)_{2}$ is thermolyzed in alkane or arene solvents in the absence of additional trapping reagents, formation of the bimetallic $[\mathrm{CpMo}(\mathrm{NO})]\left(\mu-\eta^{1}: \eta^{2}-\mathrm{NO}\right)(\mu-$ 
$\left.\mathrm{CHCMe}_{3}\right)\left[\mathrm{CpMo}\left(\mathrm{CHCMe}_{3}\right)\right]$ complex occurs. ${ }^{8}$ While the intermediate $\mathrm{CpMo}(\mathrm{NO})-$ $\left(\mathrm{CHCMe}_{3}\right)$ species can presumably undergo facile solvent coordination and exchange, the barrier to $1,2-\mathrm{CH}$ addition across the $\mathrm{Mo}=\mathrm{CHR}$ bond is comparatively large. Instead of activating solvent $\mathrm{C}-\mathrm{H}$ bonds, the alkylidene species is eventually trapped by another molecule of $\mathrm{CpMo}(\mathrm{NO})\left(\mathrm{CHCMe}_{3}\right)$ to afford the observed bimetallic product. The present calculations suggest that once the corresponding $\mathrm{W}$ alkylidene intermediate is bound to an alkane solvent molecule, the competing dissociation and activation processes are almost equally facile.

$\mathbf{C p M}(\mathbf{N O})\left(\mathbf{C H}_{2}\right)$. The intermediacy of reactive, unsaturated $\mathrm{Cp}^{*} \mathrm{~W}(\mathrm{NO})\left(\mathrm{CHCMe}_{3}\right)$ and $\mathrm{CpMo}(\mathrm{NO})\left(\mathrm{CHCMe}_{3}\right)$ in the thermolytic reactions of the corresponding bis(neopentyl) compounds has been established experimentally using kinetics, labelling, and trapping experiments. ${ }^{6,8-10}$ The optimized geometry of $\mathrm{CpW}(\mathrm{NO})\left(\mathrm{CH}_{2}\right)$ at the current level of theory was recently reported;24 the calculated structure of the corresponding CpMo(NO)$\left(\mathrm{CH}_{2}\right)$ species is illustrated in Figure 5. As previously observed for singlet $\mathrm{CpW}(\mathrm{NO})(\mathrm{L})$ species and other $16 \mathrm{e} \mathrm{CpML}_{2}$ compounds, ${ }^{22-25,34}$ singlet $\mathrm{CpMo}(\mathrm{NO})\left(\mathrm{CH}_{2}\right)$ is highly pyramidal at metal, with a $\mathrm{ON}-\mathrm{Mo}-\mathrm{CP}-\mathrm{CH}_{2}$ dihedral angle of $120.2^{\circ}$. It should be noted that since the bond lengths and angles are relatively invariant between the free $16 \mathrm{e}$ alkylidene species and the $\mathrm{CpMo}(\mathrm{NO})\left(\mathrm{CH}_{2}\right)$ fragment in the $\mathrm{CH}_{4}$ (or $\mathrm{NH}_{3}$ ) adducts, very little reorganization is expected to be required in order to bind these molecules.

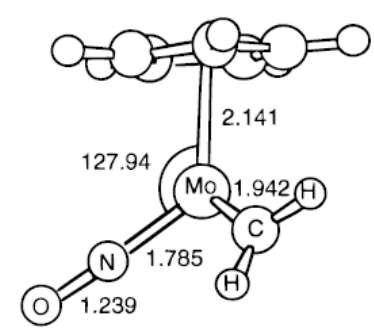

Figure 5. Optimized geometry of $\mathrm{CpMo}(\mathrm{NO})\left(\mathrm{CH}_{2}\right)$. 
N-H Bond Activation. $\mathbf{C p M}(\mathbf{N O})\left(\mathbf{C H}_{2}\right)\left(\mathbf{N H}_{3}\right)$. The optimized geometries calculated for the reaction of $\mathrm{CpM}(\mathrm{NO})\left(\mathrm{CH}_{2}\right)$ with $\mathrm{NH}_{3}$ are illustrated in Figure 6. The coordinated $\mathrm{NH}_{3}$ group in the ammonia adduct depicted in Figure 6(a) has one $\mathrm{H}$ that is bent slightly towards the metal, leading to a difference in $\mathrm{H}-\mathrm{N}-\mathrm{M}$ angles analogous to those seen in the $\mathrm{CpM}(\mathrm{NO})\left(\mathrm{CH}_{3}\right)_{2}$ complex. In the $\mathrm{NH}_{3}$ group, this discrepancy between the angles (104.0 and $103.6^{\circ}$ vs. $111.0-112.4^{\circ}$ for Mo and $\mathrm{W}$, respectively) is not as pronounced as in the $\mathrm{CH}_{3}$ groups discussed previously. Unlike the $16 \mathrm{e}$ bis(methyl) complex, the metal-alkylidene $\pi$ bond in $\mathrm{CpM}(\mathrm{NO})\left(\mathrm{CH}_{2}\right)\left(\mathrm{NH}_{3}\right)$ results in an $18 \mathrm{e}$ compound which is less prone to seek additional electron density from the $\alpha-\mathrm{H}$ atoms of the ancillary ligands.

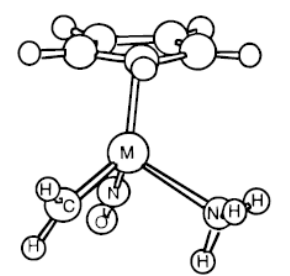

(a)
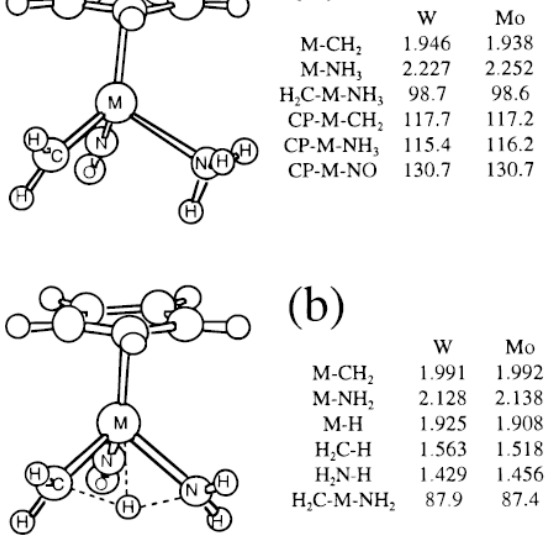

(b)
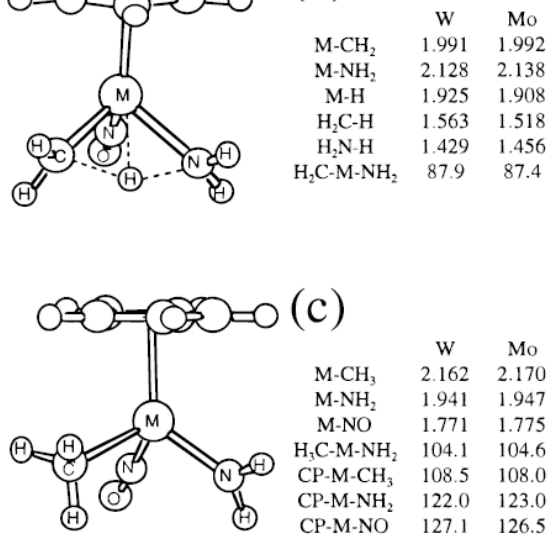

Figure 6. Optimized geometries of (a) $\mathrm{CpM}(\mathrm{NO})\left(\mathrm{CH}_{2}\right)\left(\mathrm{NH}_{3}\right)$, (b) $\mathrm{CpM}(\mathrm{NO})$ $\left(\mathrm{H}_{2} \mathrm{C} \cdots \mathrm{H} \cdots \mathrm{NH}_{2}\right)$, and (c) $\mathrm{CpM}(\mathrm{NO})\left(\mathrm{CH}_{3}\right)\left(\mathrm{NH}_{2}\right)$.

The $\mathrm{CpM}(\mathrm{NO})\left(\mathrm{CH}_{2}\right)\left(\mathrm{NH}_{3}\right)$ complexes are much more stable with respect to the 16e alkylidene and free ligand compared to $\mathrm{CpM}(\mathrm{NO})\left(\mathrm{CH}_{2}\right)\left(\mathrm{CH}_{4}\right)$, as expected on the 
basis of the relative ligating abilities of ammonia and methane. In contrast to the methane activation process, no distinct $\eta^{2}-\mathrm{N}, \mathrm{H}$ ammonia adduct was located along the $\mathrm{N}-\mathrm{H}$ activation reaction coordinate.

$\mathbf{C p M}(\mathbf{N O})\left(\mathbf{H}_{2} \mathbf{C} \cdots \mathbf{H} \cdots \mathbf{N H}_{2}\right)$. The transition state for the $\mathrm{N}-\mathrm{H}$ activation process is displayed in Figure 6(b). Frequency calculations confirm that this geometry is located on a first-order saddle point. Analogous to the $\mathrm{C}-\mathrm{H}$ activation process, the reaction consists of a metal-assisted 1,2- $\mathrm{NH}$ addition across the $\mathrm{M}=\mathrm{C}$ double bond, without a distinct $\mathrm{CpM}(\mathrm{NO})\left(\mathrm{NH}_{2}\right)\left(\mathrm{CH}_{2}\right) \mathrm{H}$ intermediate. The planarity of the $\mathrm{H}_{2} \mathrm{CM}$ moiety is distorted to a much greater extent than in the corresponding methane activation: the $\mathrm{H}-\mathrm{C}-\mathrm{M}-\mathrm{H}$ dihedral angle of the carbene group is 165.8 and $168.3^{\circ}$ for Mo and $\mathrm{W}$, respectively, for the $\mathrm{N}-\mathrm{H}$ activation transition state, compared to the almost completely planar values of 179.7 and $179.9^{\circ}$ for Mo and $\mathrm{W}$, respectively, for the analogous $\mathrm{C}-\mathrm{H}$ activation. Comparing the $\mathrm{M}-\mathrm{C}$ and $\mathrm{M}-\mathrm{N}$ bond lengths in the transition state to those calculated for the $\mathrm{CpM}(\mathrm{NO})\left(\mathrm{CH}_{2}\right)\left(\mathrm{NH}_{3}\right)$ and $\mathrm{CpM}(\mathrm{NO})\left(\mathrm{CH}_{3}\right)\left(\mathrm{NH}_{2}\right)$ complexes indicates that although the $\mathrm{N}-\mathrm{H}$ activation transition state geometry does lie closer to the ammonia adduct, this structural similarity between adduct and transition state is not as pronounced as that described for the $\mathrm{C}-\mathrm{H}$ activation process.

This difference between the two transition states can be traced to their relative energies on their respective reaction coordinates. Unlike the $\mathrm{CpM}(\mathrm{NO})\left(\mathrm{CH}_{2}\right)+\mathrm{CH}_{4}$ reaction, the transition state for $\mathrm{N}-\mathrm{H}$ activation is not close in energy to either reactants or products, and so is not expected to bear a striking resemblance to either species. Although the transition state is much higher in energy with respect to the adduct than is observed for the $\mathrm{C}-\mathrm{H}$ activation process, the transition state is still significantly more stable than the free $\mathrm{CpM}(\mathrm{NO})\left(\mathrm{CH}_{2}\right)$ and $\mathrm{NH}_{3}$, by 9.2 and $19.8 \mathrm{kcal} / \mathrm{mol}$ for Mo and $\mathrm{W}$, respectively.

CpM(NO)(CH3)(NH2). As shown in Figure 6(c), the geometry of $\mathrm{CpM}(\mathrm{NO})\left(\mathrm{CH}_{3}\right)\left(\mathrm{NH}_{2}\right)$ is distorted slightly from the ideal $\mathrm{CpML}_{3}$ geometry. The deformations involve the 
methyl ligand bond angles, although the distortions are not as pronounced as in the $\mathrm{CpM}(\mathrm{NO})\left(\mathrm{CH}_{3}\right)_{2}$ or $\mathrm{CpM}(\mathrm{NO})\left(\mathrm{CH}_{2}\right)\left(\mathrm{NH}_{3}\right)$ species. The $\mathrm{H}_{2} \mathrm{NM}$ group is essentially planar and is aligned with the $\mathrm{M}-\mathrm{NO}$ axis, as indicated by the $\mathrm{H}-\mathrm{N}-\mathrm{M}-\mathrm{H}$ and $\mathrm{H}-\mathrm{N}-\mathrm{M}-\mathrm{N}(\mathrm{O})$ dihedral angles, all of which are close to 0 or $180^{\circ}$. The short $\mathrm{Mo}-\mathrm{NH}_{2}$ and $\mathrm{W}-\mathrm{NH}_{2}$ bond lengths (1.941 and $1.947 \AA$, respectively) and the planarity and alignment of the amido moiety are all consistent with the presence of a strong $\mathrm{M}-\mathrm{N} \pi$ bonding interaction.

The strength of the metal-amido $\pi$ bond also provides a rationale for the relative stability of the $\mathrm{CpM}(\mathrm{NO})\left(\mathrm{CH}_{3}\right)\left(\mathrm{NH}_{2}\right)$ complexes. Compared to free $\mathrm{CpM}(\mathrm{NO})\left(\mathrm{CH}_{2}\right)$ and ammonia, the methyl amido compounds are more stable by 56.0 and $69.9 \mathrm{kcal} / \mathrm{mol}$ for Mo and $\mathrm{W}$, respectively. While this enormous stabilization may be due in part to the $\sigma$ bonding component of the $\mathrm{M}-\mathrm{NH}_{2}$ linkage, it seems likely that $\pi$ donation from the filled $\mathrm{p}$ orbital on the amido $\mathrm{N}$ atom into the empty metal-based orbital perpendicular to the metal-nitrosyl bond also plays a significant role. It is interesting to compare the relative exothermicity of the addition of $\mathrm{NH}_{3}$ and $\mathrm{CH}_{4}$ to $\mathrm{CpM}(\mathrm{NO})\left(\mathrm{CH}_{2}\right)$ to a previous study of $\mathrm{C}-\mathrm{H}$ and $\mathrm{N}-\mathrm{H}$ activation by the $16 \mathrm{e} \mathrm{CpRh}(\mathrm{CO})$ species. ${ }^{35}$ Musaev and Morokuma found that although ammonia formed a much stronger adduct than methane to the $\mathrm{CpRh}(\mathrm{CO})$ fragment, the formation of the $\mathrm{C}-\mathrm{H}$ activation product $\mathrm{CpRh}(\mathrm{CO})\left(\mathrm{CH}_{3}\right) \mathrm{H}$ was much more exothermic than the generation of $\mathrm{CpRh}(\mathrm{CO})\left(\mathrm{NH}_{2}\right) \mathrm{H}$ from $\mathrm{N}-\mathrm{H}$ activation. This difference was attributed to the relative weakness of the $\mathrm{Rh}-\mathrm{N}$ bond due to the strong repulsion between the metal d electrons and the ligand lone pair. 35 While such "filledfilled repulsions" is a common phenomenon in late metal amido complexes, 36,37 the presence of a stabilizing ligand-to-metal $\pi$ donation in the $\mathrm{CpM}(\mathrm{NO})\left(\mathrm{CH}_{3}\right)\left(\mathrm{NH}_{2}\right) \mathrm{d}^{4}$ complexes results in the opposite energetic trend for $\mathrm{C}-\mathrm{H}$ vs. $\mathrm{N}-\mathrm{H}$ activation in this system. The large barrier to the regeneration of $\mathrm{CpM}(\mathrm{NO})\left(\mathrm{CH}_{2}\right)$ via elimination of ammonia from $\mathrm{CpM}(\mathrm{NO})\left(\mathrm{CH}_{3}\right)\left(\mathrm{NH}_{2}\right)$ helps explain the enhanced thermal stability of $\mathrm{CpMo}(\mathrm{NO})\left(\mathrm{CH}_{2} \mathrm{CMe}_{3}\right)\left(\mathrm{NR}_{2}\right)$ derivatives compared to the bis(neopentyl) precursors. ${ }^{9}$ 
Adduct Formation. Since the initial synthesis of the $16 \mathrm{e} \mathrm{CpM}(\mathrm{NO})(\text { alkyl })_{2}$ complexes, ${ }^{26}$ the reactivity of the metal-alkyl bonds with small molecules such as $\mathrm{H}_{2}$, $\mathrm{CO}, \mathrm{H}_{2} \mathrm{O}$ and $\mathrm{O}_{2}$ has been a topic of ongoing research. These reactions are generally presumed to proceed via initial coordination to the metal at the position trans to the NO group. ${ }^{18}$ The two possible $\mathrm{CpM}(\mathrm{NO})\left(\mathrm{CH}_{3}\right)_{2}\left(\mathrm{NH}_{3}\right)$ isomers were examined to explore the selectivity of nucleophilic attack and to gauge the relative Lewis acidities of Mo and W.

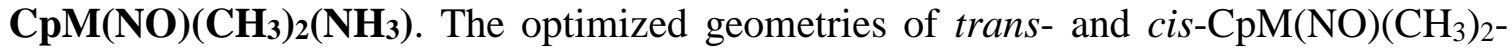
$\left(\mathrm{NH}_{3}\right)$ are remarkably similar, as shown in Figure 7(a) and 7(b), respectively. The favored trans isomers are calculated to be 15.8 and $16.0 \mathrm{kcal} / \mathrm{mol}$ more stable than $\mathrm{CpM}(\mathrm{NO})\left(\mathrm{CH}_{3}\right)_{2}$ and free ammonia for $\mathrm{W}$ and Mo, respectively, while the corresponding cis isomers are found to be stabilized by only 10.6 and $9.3 \mathrm{kcal} / \mathrm{mol}$. The $\mathrm{M}-\mathrm{CH}_{3}$ and $\mathrm{M}-\mathrm{NH}_{3}$ bond lengths are elongated by roughly 0.10 to $0.05 \AA$ compared to the more coordinatively-unsaturated compounds in Figures 3 and 6, with the ligand trans to the nitrosyl typically displaying the most pronounced lengthening. With regard to the bond angles, two distinct deformations from an ideal pseudo- $C_{4 \mathrm{v}} \mathrm{CpML}_{4}$ geometry can be discerned, involving (i) the $\mathrm{CP}-\mathrm{M}-\mathrm{L}$ angles and (ii) the bending of the groups cis to the NO away from the nitrosyl ligand.

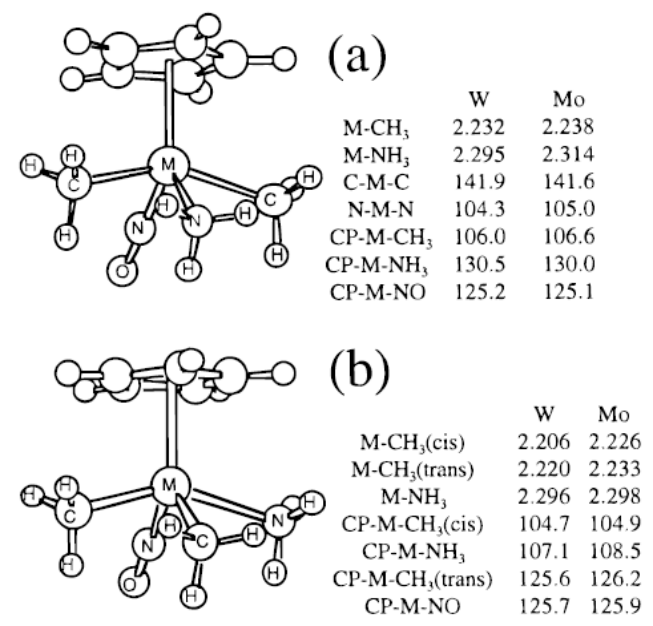


Figure 7. Optimized geometries of (a) trans-CpM(NO) $\left(\mathrm{CH}_{3}\right)_{2}\left(\mathrm{NH}_{3}\right)$ and (b) cis$\mathrm{CpM}(\mathrm{NO})\left(\mathrm{CH}_{3}\right)_{2}\left(\mathrm{NH}_{3}\right)$.

The first distortion is a well-recognized hallmark of $\mathrm{CpML}_{4}$ chemistry, ${ }^{21,38}$ and is controlled by the relative $\sigma$-bonding properties of pairs of mutually trans ligands. ${ }^{39}$ The two trans ligands capable of the strongest covalent $\sigma$ bonding will possess small $\mathrm{CP}-\mathrm{M}-\mathrm{L}$ angles approaching a minimum of $90^{\circ}$, while the other two ligands will adopt large $\mathrm{CP}-\mathrm{M}-\mathrm{L}$ angles of up to $135^{\circ}$. The $\mathrm{CP}-\mathrm{M}-\mathrm{L}$ angles shown in Figure 7(a) and 7(b) are consistent with the relative $\sigma$-bonding abilities of the $\mathrm{L}$ groups. The thermodynamic preference of trans-CpM(NO) $\left(\mathrm{CH}_{3}\right)_{2}\left(\mathrm{NH}_{3}\right)$ over the cis isomer is attributed to the optimal pairing of the two trans methyl groups while the comparatively weak $\sigma$ donor $\mathrm{NH}_{3}$ is opposite the nitrosyl ligand. The large $\mathrm{CP}-\mathrm{M}-\mathrm{NO}$ angle is also required for efficient nitrosyl $\pi$ bonding with the two occupied metal d orbitals. 21,38

The second angular distortion in both $\mathrm{CpM}(\mathrm{NO})\left(\mathrm{CH}_{3}\right)_{2}\left(\mathrm{NH}_{3}\right)$ isomers induces the groups cis to NO to bend away from the nitrosyl ligand, resulting in a compression of the comparatively large methyl and ammine ligands that is completely contrary to steric expectations. The electronic origins of this deformation in trans-CpM(NO) $\left(\mathrm{CH}_{3}\right)_{2}\left(\mathrm{NH}_{3}\right)$ are illustrated schematically in Figure 8. In the idealized structure in Figure 8(a), the metal, the Cp centroid, and the two $\mathrm{N}$ atoms lie on the mirror plane of the complex, while the two methyl $\mathrm{C}$ atoms, the metal, and the $\mathrm{Cp}$ centroid define a second plane perpendicular to the $C_{\mathrm{s}}$ plane. The HOMO of the complex is $\mathrm{M}-\mathrm{NO} \pi$ bonding in character, and has nodal planes that coincide with the two planes containing the $\mathrm{M}-\mathrm{L}$ axes. In the optimized structure, the movement of the methyl ligands towards the $\mathrm{NH}_{3}$ group moves the $\mathrm{M}-\mathrm{CH}_{3}$ axes away from the HOMO nodal plane. As shown in Figure 8(b), this compression allows the HOMO to distort in order to improve the overlap with the $\mathrm{N}-\mathrm{O} \pi^{*}$ orbitals, thereby strengthening the $\mathrm{M}-\mathrm{NO} \pi$ bond and lowering the HOMO energy. 


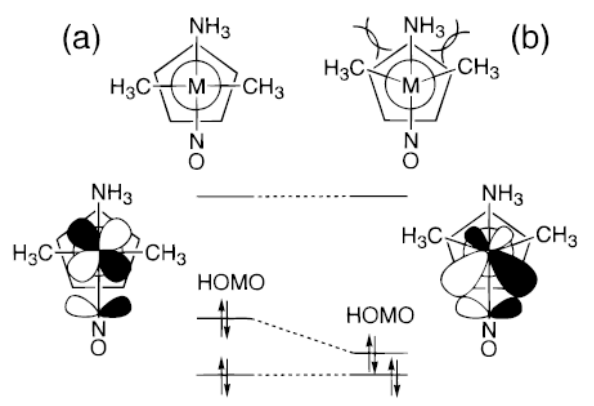

Figure 8. Qualitative diagram of frontier MO energies for (a) trans-CpM(NO)(CH$)_{2}$ $\left(\mathrm{NH}_{3}\right)$ with $\mathrm{H}_{3} \mathrm{C}-\mathrm{M}-\mathrm{CP}-\mathrm{CH}_{3}$ dihedral angle $=180^{\circ}$ and (b) trans-CpM(NO)$\left(\mathrm{CH}_{3}\right)_{2}\left(\mathrm{NH}_{3}\right)$ with $\mathrm{CH}_{3}$ groups bent towards $\mathrm{NH}_{3}$. Pictorial representation of HOMO for (a) and (b), as viewed down the M-CP axis.

Comparison with Experimental Systems. Nitrosyl stretching frequencies provide both a convenient spectroscopic handle and a rough gauge of the electron density at the metal center in $\mathrm{CpM}(\mathrm{NO})$-containing complexes. Table 1 shows the calculated $v(\mathrm{NO})$ values for the more stable compounds, along with relevant experimental values. $6,9,40-42$ The Mo frequencies are calculated to be $\sim 20 \mathrm{~cm}^{-1}$ higher than for $\mathrm{W}$, accurately reflecting the experimentally-observed trend. ${ }^{18}$ However, the calculated values are uniformly higher than the experimental frequencies, by up to $70 \mathrm{~cm}^{-1}$ or more for the methyl amido compounds. This discrepancy is likely due to the neglect of anharmonicity effects in the computational technique, which is known to lead to inflated calculated frequencies. ${ }^{43}$ The simplified model compounds may also be partially responsible for the systematic increase in $v(\mathrm{NO})$, especially since the large hydrocarbyl groups at the periphery of the alkyl, amido, and Cp ligands typically employed experimentally have been replaced with less-electron donating $\mathrm{H}$ atoms.

Table 1. Calculated and Experimental Nitrosyl Stretching Frequencies

\begin{tabular}{cc|ccc} 
Calculated & $v(\mathrm{NO}), \mathrm{cm}^{-1}$ & Experimental $^{\mathrm{a}}$ & ref. \\
\hline $\mathrm{CpW}(\mathrm{NO})\left(\mathrm{NH}_{3}\right)\left(\mathrm{CH}_{2}\right)$ & 1563 & 1513 & $\mathrm{Cp} * \mathrm{~W}(\mathrm{NO})\left(\mathrm{PMe}_{3}\right)\left(\mathrm{CHCMe}_{3}\right)$ & 6 \\
\hline
\end{tabular}




\begin{tabular}{lc:clll}
$\mathrm{CpW}(\mathrm{NO})\left(\mathrm{NH}_{2}\right)\left(\mathrm{CH}_{3}\right)$ & 1598 & 1526 & $\mathrm{Cp} * \mathrm{~W}(\mathrm{NO})\left(\mathrm{NHCMe}_{3}\right)\left(\mathrm{CH}_{2} \mathrm{CMe}_{3}\right)$ & 40 \\
\hline $\mathrm{CpW}(\mathrm{NO})\left(\mathrm{CH}_{3}\right)_{2}$ & 1602 & 1572 & $\mathrm{Cp} * \mathrm{~W}(\mathrm{NO})\left(\mathrm{CH}_{2} \mathrm{SiMe}_{3}\right)_{2}$ & 41 \\
\hline $\mathrm{CpMo}(\mathrm{NO})\left(\mathrm{NH}_{3}\right)\left(\mathrm{CH}_{2}\right)$ & 1579 & 1540 & $\mathrm{CpMo}(\mathrm{NO})\left(\mathrm{PPh}_{2} \mathrm{Me}\right)\left(\mathrm{CHCMe}_{3}\right)$ & 9 \\
\hline $\mathrm{CpMo}(\mathrm{NO})\left(\mathrm{NH}_{2}\right)\left(\mathrm{CH}_{3}\right)$ & 1624 & 1554 & $\mathrm{CpMo}(\mathrm{NO})\left(\mathrm{NHCMe}_{3}\right)\left(\mathrm{CH}_{2} \mathrm{CMe}_{3}\right)$ & 9 \\
\hline $\mathrm{CpMo}(\mathrm{NO})\left(\mathrm{CH}_{3}\right)_{2}$ & 1618 & 1595 & $\mathrm{Cp} * \mathrm{Mo}(\mathrm{NO})\left(\mathrm{CH}_{2} \mathrm{SiMe}_{3}\right)_{2}$ & 42 \\
\hline
\end{tabular}

${ }^{a}$ Nujol-mull IR spectra.

These same structural variations between the actual compounds and the computational models probably also contribute to the anomolously large calculated activation barriers. The conversion of $\mathrm{CpMo}(\mathrm{NO})\left(\mathrm{CH}_{3}\right)_{2}$ to $\mathrm{CpMo}(\mathrm{NO})\left(\mathrm{CH}_{2}\right)$ and methane has a calculated barrier of $32.7 \mathrm{kcal} / \mathrm{mol}$, compared to the value of $18.7 \mathrm{kcal} / \mathrm{mol}$ obtained from kinetic measurements of the elimination of $\mathrm{CD}_{3} \mathrm{CMe}_{3}$ from $\mathrm{CpMo}(\mathrm{NO})\left(\mathrm{CD}_{2} \mathrm{CMe}_{3}\right)_{2}$ in a variety of solvents. ${ }^{9}$ The proclivity of bulky neopentyl ligands to engage in $\alpha$ abstraction reactions at enhanced rates is well recognized, in stark contrast to the slow formation of methylene species from methyl complexes. ${ }^{28}$ While the $\mathrm{CH}_{3}$ group is an acceptable substitute for $\mathrm{CH}_{2} \mathrm{CMe}_{3}$ in order to obtain the qualitative comparisons required for the present study, a more accurate model is apparently necessary to achieve reasonable quantitative agreement with experiment. 44

The relatively subtle electronic effects that underpin the structural deformations illustrated in Figures 4 and 8 play a critical and previously unappreciated role in the characteristic reactivity of $\mathrm{CpM}(\mathrm{NO})(\text { alkyl })_{2}$ complexes. Three distinct features of these compounds contribute to their selective binding of small molecules and subsequent intramolecular reactions with the metal-carbon bonds. The large $\mathrm{C}-\mathrm{M}-\mathrm{C}$ angle renders the metal prone to nucleophilic attack trans to the NO group by available L ligands. The disparity in $\sigma$ - and $\pi$-bonding properties between the alkyl and nitrosyl groups thermodynamically favors the isomer with L trans to the NO. However, the compression 
of the groups cis to $\mathrm{NO}$ in $\mathrm{CpM}(\mathrm{NO})(\text { alkyl })_{2}(\mathrm{~L})$ complexes increases the steric strain in these complexes, particularly when the bulky alkyl groups typical for this system (e.g. $\left.\mathrm{CH}_{2} \mathrm{CMe}_{3}, \mathrm{CH}_{2} \mathrm{CMe}_{2} \mathrm{Ph}, \mathrm{CH}_{2} \mathrm{SiMe}_{3}\right)$ are employed. The electronically-dictated small $\mathrm{C}-\mathrm{M}-\mathrm{L}$ angles introduces a degree of steric selection in the binding of $\mathrm{L}$ to $\mathrm{CpM}(\mathrm{NO})(\text { alkyl) })_{2}$ compounds, discouraging the coordination of larger molecules (e.g. coordinating solvents, the $\mathrm{O}$ atom of another $\mathrm{CpM}(\mathrm{NO})(\text { alkyl })_{2}$ molecule) that could otherwise compete for the open coordination site at the metal.

The relative energies of cis and trans isomers of $\mathrm{CpM}(\mathrm{NO})(\mathrm{X})_{2}(\mathrm{~L})$ complexes is highly dependent on the nature of the $\mathrm{X}$ ligands. The trans form is favored experimentally when $\mathrm{X}=\mathrm{CH}_{2} \mathrm{R}$ or $\mathrm{H}$, since the $\mathrm{L}$ groups are typically poorer $\sigma$ donors than the alkyl or hydride ligands. However, if $\mathrm{X}=$ halide, the phosphine L ligands prefer to coordinate cis to the nitrosyl, as determined by ${ }^{1} \mathrm{H}$ NMR studies for $\mathrm{CpMo}(\mathrm{NO})(\mathrm{I})_{2}\left(\mathrm{PMe}{ }_{2} \mathrm{Ph}\right)^{45}$ and related $\mathrm{CpM}(\mathrm{NO})(\mathrm{X})_{2}(\mathrm{~L})$ and $\left[\mathrm{CpM}(\mathrm{NO})(\mathrm{X})(\mathrm{L})_{2}\right]^{+}$ complexes, ${ }^{46-48}$ and by X-ray crystallography for $\mathrm{CpMo}(\mathrm{NO})\left(\mathrm{CH}_{3}\right)(\mathrm{Br})\left(\mathrm{PPh}_{3}\right) .{ }^{49}$ Care must therefore be taken before extending the observations based on the bis(alkyl) complexes to other $\mathrm{CpM}(\mathrm{NO})(\mathrm{X})_{2}(\mathrm{~L})$ systems such as $\mathrm{Cp} * \mathrm{M}(\mathrm{NO})\left(\mathrm{CH}_{2} \mathrm{CMe}_{3}\right)(\mathrm{Cl})$ $\left(\mathrm{PMe}_{3}\right){ }^{29}$

The optimized geometries of the singlet $\mathrm{CpM}(\mathrm{NO})\left(\mathrm{CH}_{3}\right)_{2}, \mathrm{CpM}(\mathrm{NO})\left(\mathrm{CH}_{2}\right)\left(\mathrm{NH}_{3}\right)$, $\mathrm{CpM}(\mathrm{NO})\left(\mathrm{CH}_{3}\right)\left(\mathrm{NH}_{2}\right)$, and $\mathrm{CpM}(\mathrm{NO})\left(\mathrm{CH}_{3}\right)_{2}\left(\mathrm{NH}_{3}\right)$ complexes are in relatively good agreement with corresponding structures characterized by X-ray crystallography as tabulated in the Supporting Information. 50 The correlation between the DFT and X-ray results is the poorest for bond angles that are susceptible to steric effects, especially when the simplified ligands in the model complex differ markedly from the closest known experimental structure (e.g. $\mathrm{Cp}$ vs. $\mathrm{Cp}^{*}, \mathrm{NH}_{3}$ vs. $\mathrm{PMe}_{3}$ ). However, in each complex, bonding parameters that are primarily influenced by electronic effects display particularly good agreement with experimental values, such as the $\mathrm{H}_{3} \mathrm{C}-\mathrm{M}-\mathrm{CH}_{3}$ angles and the nitrosyl-alkylidene (or nitrosyl-amido) orientations discussed above. 
Relative Orbital Energies. Many of the interpretations presented in this paper have been based on the energies and bonding characteristics of the frontier orbitals of the optimized structures. A potential problem underlying this approach is the fact that the Kohn-Sham orbitals obtained from DFT calculations are inherently different than the orbitals resulting from Hartree-Fock or EHMO techniques. Hoffmann and co-workers have recently demonstrated the similarity between these different types of orbitals, indicating that Kohn-Sham orbitals do indeed provide a suitable basis for the qualitative analysis of chemical problems. ${ }^{51}$ This study noted, however, that the Kohn-Sham orbital energies require the application of a linear scaling factor in order to obtain quantitative agreement with energies calculated by Hartree-Fock or EHMO techniques.

Despite these reservations, comparing the relative orbital energies for congeneric Mo and $\mathrm{W}$ complexes reveals that with the sole exception of the LUMO of CpM(NO)$\left(\mathrm{CH}_{2}\right)$, the frontier orbitals are lower in energy than for Mo than for $W$ in all of the singlet reactants, products, and intermediates. This observation provides an interesting rationale for many of the reactivity differences observed in the present system. The decreased energy of the two highest-lying occupied orbitals, the HOMO and SHOMO, for Mo results in poorer $\pi$-backbonding with the unoccupied, relatively high-lying nitrosyl $\mathrm{N}-\mathrm{O} \pi^{*}$ orbitals, as reflected in the uniformly higher $v(\mathrm{NO})$ values for Mo than for $\mathrm{W}$. The lower energy of the LUMO in $\mathrm{CpMo}(\mathrm{NO})\left(\mathrm{CH}_{3}\right)_{2}$ is consistent with the marked tendency of the $\mathrm{CpMo}(\mathrm{NO})(\text { alkyl })_{2}$ complexes to form $\mathrm{L}$ adducts more readily than the corresponding $\mathrm{W}$ species. ${ }^{18}$ The larger $\mathrm{C}-\mathrm{M}-\mathrm{C}$ angles for Mo than for $\mathrm{W}$ observed experimentally in the bis(alkyl) compounds may also be traced to the lowerenergy LUMO for Mo, which presumably mixes more readily with occupied orbitals thereby enhancing the second-order Jahn-Teller effect illustrated schematically in Figure 4. 
Singlet and Triplet Spin States. Spin state effects are increasingly being recognized as playing a crucial role in element-hydrogen activation reactions by unsaturated 16e species. Ultrafast infrared spectroscopic techniques and DFT calculations have demonstrated that triplet $\mathrm{CpML}_{\mathrm{n}}$ complexes such as $\mathrm{CpMn}(\mathrm{CO})_{2}$ or $\mathrm{CpCo}(\mathrm{CO})$ interact only weakly with alkane $\mathrm{C}-\mathrm{H}$ bonds, yet react readily with better ligands such as $\mathrm{Si}-\mathrm{H}$ bonds or $\mathrm{CO} .{ }^{34,52,53}$ As part of an ongoing investigation into spin state changes in organometallic compounds, 54,55 we have recently used DFT techniques to examine spin state effects in unsaturated $\mathrm{CpML}_{\mathrm{n}}$ species, ${ }^{56}$ including $\mathrm{CpM}(\mathrm{NO})$ complexes of $\mathrm{Cr}$, Mo, and W.24,57,58

In a previous study, the ligand effects on the relative energies of the singlet and triplet spin states were examined for $\mathrm{CpCr}(\mathrm{NO})\left(\mathrm{CH}_{3}\right) \mathrm{X}$ complexes $\left(\mathrm{X}=\mathrm{CH}_{3}\right.$ or $\left.\mathrm{NH}_{2}\right) ; 5$ for comparison, these $\Delta \mathrm{E}_{\mathrm{ST}}\left(\Delta \mathrm{E}_{\mathrm{ST}}=\Delta \mathrm{E}\right.$ (triplet $)-\Delta \mathrm{E}$ (singlet) $)$ results are displayed in Table 2 along with the new values obtained for the heavier Group 6 congeners.

Table 2. $\Delta \mathrm{E}_{\mathrm{ST}}$ for $\mathrm{CpM}(\mathrm{NO})\left(\mathrm{CH}_{3}\right) \mathrm{X}\left(\mathrm{M}=\mathrm{Cr}, \mathrm{Mo}, \mathrm{W} ; \mathrm{X}=\mathrm{CH}_{3}, \mathrm{NH}_{2}\right)^{\mathrm{a}}$

\begin{tabular}{ccc} 
& $\mathrm{X}=\mathrm{CH}_{3}$ & $\mathrm{X}=\mathrm{NH}_{2}$ \\
\hline $\mathrm{Cr}$ & $2.4^{\mathrm{b}}$ & $9.6^{\mathrm{b}}$ \\
\hline $\mathrm{Mo}$ & 21.4 & 27.9 \\
\hline $\mathrm{W}$ & 23.1 & 31.5 \\
\hline
\end{tabular}

${ }^{\mathrm{a}} \Delta \mathrm{E}_{\text {ST }}$ in $\mathrm{kcal} / \mathrm{mol} .{ }^{\mathrm{b}} \mathrm{CpCr}(\mathrm{NO})\left(\mathrm{CH}_{3}\right) \mathrm{X}$ values from ref 57.

The optimized geometries of triplet $\mathrm{CpM}(\mathrm{NO})\left(\mathrm{CH}_{3}\right)_{2}$ are shown in Figure 9(a). In the $\mathrm{CpM}(\mathrm{NO})\left(\mathrm{CH}_{3}\right)_{2}$ compounds, the nitrosyl ligand is bent down with respect to the $\mathrm{Cp}$ centroid, while the $\mathrm{C}-\mathrm{M}-\mathrm{C}$ angle is compressed to very close to the pseudo-octahedral value of $90^{\circ}$. Unlike $\mathrm{CpCr}(\mathrm{NO})\left(\mathrm{CH}_{3}\right)_{2}$ which exhibits a very small singlet-triplet gap, the Mo and $\mathrm{W}$ complexes display a substantial preference for the singlet configuration. 

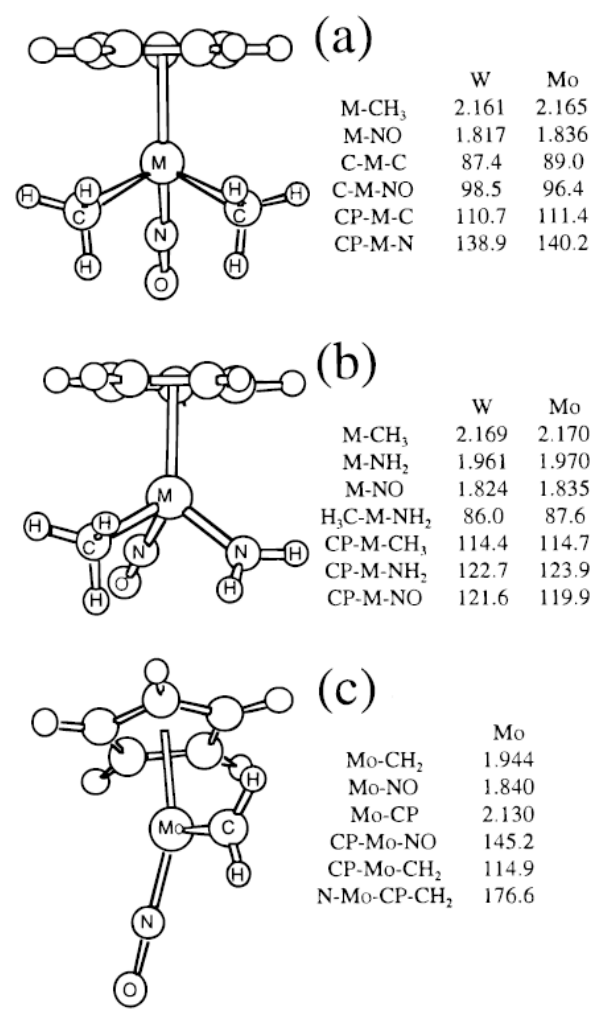

Figure 9. Optimized geometries of (a) triplet $\mathrm{CpM}(\mathrm{NO})\left(\mathrm{CH}_{3}\right)_{2}$, (b) triplet $\mathrm{CpM}(\mathrm{NO})$ $\left(\mathrm{CH}_{3}\right)\left(\mathrm{NH}_{2}\right)$, and (c) triplet $\mathrm{CpMo}(\mathrm{NO})\left(\mathrm{CH}_{2}\right)$.

The triplet $\mathrm{CpM}(\mathrm{NO})\left(\mathrm{NH}_{2}\right)\left(\mathrm{CH}_{3}\right)$ geometries shown in Figure 9(b) also exhibit reduced $\mathrm{H}_{3} \mathrm{C}-\mathrm{M}-\mathrm{NH}_{2}$ angles compared to the singlet structures. While the $\mathrm{MNH}_{2}$ group remains planar, the amido group has rotated to lie perpendicular to the $\mathrm{M}-\mathrm{NO}$ axis instead of the experimentally-observed planar conformation adopted by the singlet species. The presence of the amido group enhances the relative stability of the singlet state, as shown by the increased $\Delta \mathrm{E}_{\mathrm{ST}}$ values for $\mathrm{CpM}(\mathrm{NO})\left(\mathrm{NH}_{2}\right)\left(\mathrm{CH}_{3}\right)$ compared to the bis(methyl) compounds. The relative stability of the singlet spin state compared to the triplet again follows the periodic trend $\mathrm{W}>\mathrm{Mo}>>\mathrm{Cr}$. As expected, the $\mathrm{M}-\mathrm{NO}$ bond is elongated in all of the triplet species due to partial depopulation of the metal-nitrosyl $\pi$ bonding orbitals, although this variation is not as pronounced as that previously noted for the corresponding $\mathrm{Cr}$ complexes. ${ }^{57}$ 
In a previous computational study, singlet $\mathrm{CpW}(\mathrm{NO})\left(\mathrm{CH}_{2}\right)$ was calculated to be only $2.4 \mathrm{kcal} / \mathrm{mol}$ more stable than triplet $\mathrm{CpW}(\mathrm{NO})\left(\mathrm{CH}_{2}\right){ }^{24}$ Extending these calculations to the Mo complex reveals that $\mathrm{CpMo}(\mathrm{NO})\left(\mathrm{CH}_{2}\right)$ favors the singlet spin state to an even greater extent, namely $9.0 \mathrm{kcal} / \mathrm{mol}$. As shown in Figure 9(c), the plane containing the $\mathrm{MoCH}_{2}$ moiety remains aligned with the Mo-NO axis, and the $\mathrm{Mo}-\mathrm{CH}_{2}$ length is relatively invariant compared to the singlet state. The Mo-NO distance is longer in the triplet species, and the geometry at Mo is planar for the triplet as indicated by the $\mathrm{ON}-\mathrm{Mo}-\mathrm{CP}-\mathrm{CH}_{2}$ dihedral angle of $176.6^{\circ}$. This difference in conformation at metal between singlet and triplet spin states has previously been observed in computational studies of $\mathrm{CpW}(\mathrm{NO})(\mathrm{L})$ complexes, ${ }^{24,58}$ as well as for $\mathrm{CpMn}(\mathrm{CO})_{2}$ and $\left[\mathrm{CpFeL}_{2}\right]^{+}$species. $^{25,34}$

Although the large $\Delta \mathrm{E}_{\mathrm{ST}}$ values calculated for the $\mathrm{CpM}(\mathrm{NO})\left(\mathrm{CH}_{2}\right)$ complexes preclude the direct involvement of the triplet spin state in the $\mathrm{C}-\mathrm{H}$ or $\mathrm{N}-\mathrm{H}$ bond activation processes, it is interesting to compare the singlet-triplet energy gaps for the 16e Mo and $\mathrm{W}$ alkylidene species and their differences in reactivity. Su and Chu have performed computational studies on several $\mathrm{C}-\mathrm{H}$ bond activating systems involving congeneric $\mathrm{Rh} / \mathrm{Ir}$ or $\mathrm{Pd} / \mathrm{Pt}$ compounds, and have noted that the $16 \mathrm{e}$ fragments which have large singlet-triplet gaps have larger activation barriers and lower exothermicities than fragments with smaller $\Delta \mathrm{E}_{S T}$ values. ${ }^{59}$ Other related systems also adhere to this trend, with the third row species possessing a smaller $\Delta \mathrm{E}_{\mathrm{ST}}$ value, lower barriers and greater exothermicities than the second row compound. 60,61 While the $\mathrm{C}-\mathrm{H}$ and $\mathrm{N}-\mathrm{H}$ bond activations reported here do not proceed via the same oxidative addition mechanism common to the aforementioned systems, it is worth noting that the correlation between reactivity and $\Delta \mathrm{E}_{\mathrm{ST}}$ also holds true for the $\mathrm{CpMo}(\mathrm{NO})\left(\mathrm{CH}_{2}\right)$ and $\mathrm{CpW}(\mathrm{NO})\left(\mathrm{CH}_{2}\right)$ species. 


\section{Conclusions}

Computational investigation of $\mathrm{C}-\mathrm{H}$ and $\mathrm{N}-\mathrm{H}$ bond activation by $\mathrm{CpM}(\mathrm{NO})\left(\mathrm{CH}_{2}\right)$ provides a qualitative rationale for the distinct reactivity profiles observed for Mo and $\mathrm{W}$ compounds. While the optimized geometries along the calculated pathway are remarkably similar for the two metals, the 1,2-additions of $\mathrm{NH}_{3}$ and $\mathrm{CH}_{4}$ across the metal-alkylidene bond of $\mathrm{CpMo}(\mathrm{NO})\left(\mathrm{CH}_{2}\right)$ are less exothermic and have greater reaction barriers than the congeneric W species. This trend is consistent with the energy gap between the singlet and triplet spin states for the $\mathrm{CpM}(\mathrm{NO})\left(\mathrm{CH}_{2}\right)$ intermediate, which is larger for Mo than for $\mathrm{W}\left(\Delta \mathrm{E}_{\mathrm{ST}}=9.0\right.$ and $2.4 \mathrm{kcal} / \mathrm{mol}$, respectively). The relative barrier heights for methane loss vs. $\mathrm{C}-\mathrm{H}$ activation from the $\mathrm{CpM}(\mathrm{NO})\left(\mathrm{CH}_{2}\right)\left(\mathrm{CH}_{4}\right)$ alkane complex are especially metal dependent, which offers a possible explanation for the absence of alkane or arene $\mathrm{C}-\mathrm{H}$ activation by $\mathrm{CpMo}(\mathrm{NO})(\mathrm{CHR})$ species. The formation of a strong $\mathrm{M}-\mathrm{NH}_{2} \pi$-bonding interaction helps make $\mathrm{NH}_{3}$ activation more exothermic than the reaction of $\mathrm{CpM}(\mathrm{NO})\left(\mathrm{CH}_{2}\right)$ with $\mathrm{CH}_{4}$, in contrast to late transition metal systems.

The reactivity of $\mathrm{CpM}(\mathrm{NO})(\text { alkyl })_{2}$ complexes with small molecules appears to be governed by previously unappreciated $\sigma$ - and $\pi$-bonding effects. The $\alpha$ agostic interactions, angular deformations, size selectivity and preference for trans adducts can all be interpreted in terms of electronic effects. The difference in reactivity between Mo and $\mathrm{W}$ in this class of complexes appears to be linked to their relative orbital energies, which are consistently lower for Mo than for W.

Although the simplified model compounds examined here provide useful information regarding qualitative energetic trends and electronic effects, this approach neglects important steric considerations. The current system is quite sensitive to such effects, as demonstrated by the pronounced difference in thermal stability between $\mathrm{Cp} * \mathrm{~W}(\mathrm{NO})\left(\mathrm{CH}_{2} \mathrm{CMe}_{3}\right)\left(\mathrm{CH}_{2} \mathrm{SiMe}_{3}\right)$ and $\mathrm{Cp} * \mathrm{~W}(\mathrm{NO})\left(\mathrm{CH}_{2} \mathrm{CMe}_{3}\right)_{2}$, for example. ${ }^{6}$ The 
poor quantitative agreement between calculated and experimental activation barriers are presumed to be due to steric differences between methyl and neopentyl groups.

\section{Computational Details}

All calculations were performed using Gaussian 9462 on an SGI Origin200 workstation. The LANL2DZ basis set was employed to perform geometry optimizations with a DFT approach. The three parameter form of the Becke, Lee, Tang and Parr functional (B3LYP) 63 was used in all cases, and no spatial symmetry constraints were imposed. The LANL2DZ basis set includes both Dunning and Hay's D95 sets for H, C, $\mathrm{N}$ and $\mathrm{O},{ }^{64}$ and the relativistic Electron Core Potential (ECP) sets of Hay and Wadt for Mo and W.65-67 Separate frequency calculations on the singlet species established that all the transition states, optimized by a quasi-Newton method, possessed one and only one imaginary frequency, and that the reactants and intermediates possessed no imaginary frequencies. Zero-point energy corrections were applied to the singlet species illustrated in Figure 2. The energies reported for the open shell (triplet) systems correspond to unrestricted B3LYP calculations. The mean value of the first-order wavefunction, which is not an exact eigenstate of $S^{2}$ for unrestricted calculations on the triplet systems, was considered suitable for the unambiguous identification of the spin state. Spin contamination was carefully monitored and the value of $\left\langle S^{2}\right\rangle$ for the unrestricted B3LYP systems at convergence were in the narrow 2.0083-2.0161 range for triplets.

Frontier orbital energies and spatial plots were obtained from Gaussian 94 output using Molden v3.2.68 In order to discern the source of the methyl group angular

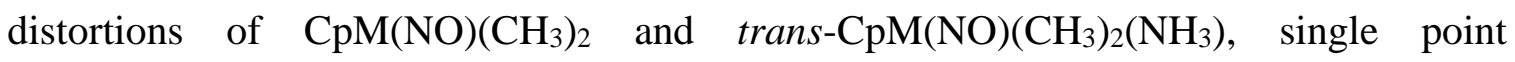
calculations were performed on idealized pseudo- $O_{\mathrm{h}}$ and pseudo- $C_{2 \mathrm{v}}$ structures. The frontier orbital energies and bonding characteristics were then compared to those 
obtained for the corresponding optimized geometries, as illustrated schematically in Figures 4 and 8.

Acknowledgment. We are grateful to Elizabeth Tran and Peter Legzdins for providing us with results prior to publication. R.P. thanks the Région Bourgogne for supporting this research, and K.M.S. thanks the European Commission for a TMR Marie Curie Postdoctoral Fellowship.

Supporting Information Available: A listing of the cartesian coordinates and final energies of all calculated complexes, tables of bond lengths and angles of selected optimized geometries with comparisons to relevant X-ray crystallographic structures, pictures and energies of the frontier orbitals for the ground state singlet structures. This material is available free of charge via the Internet at http://pubs.acs.org.

\section{References}

(1) For recent reviews of catalytic reactions involving $\mathrm{C}-\mathrm{H}^{\mathrm{a}-\mathrm{e}}$ and $\mathrm{N}-\mathrm{H}^{\mathrm{f}, \mathrm{g}}$ activation by transition metal complexes, see: (a) Sen, A. Acc. Chem. Res. 1998, 31, 550-557. (b) Stahl, S. S.; Labinger, J. A.; Bercaw, J. E. Angew. Chem. Int. Ed. 1998, 37, 21802192. (c) Dyker, G. Angew. Chem. Int. Ed. 1999, 38, 1698-1712. (d) Guari, Y.; Sabo-Etienne, S.; Chaudret, B. Eur. J. Inorg. Chem. 1999, 1047-1055. (e) Jensen, C. M. Chem. Commun. 1999, 2443-2449. (f) Wolfe, J. P.; Wagaw, S.; Marcoux, J.-F.; Buchwald, S. L. Acc. Chem. Res. 1998, 31, 805-818. (g) Hartwig, J. F. Acc. Chem. Res. 1998, 31, 852-860.

(2) (a) Saillard, J.-Y.; Hoffmann, R. J. Am. Chem. Soc. 1984, 106, 2006-2026. (b) Ziegler, T.; Tschinke, V.; Fan, L.; Becke, A. D. J. Am. Chem. Soc. 1989, 111, 91779185. (c) Koga, N.; Morokuma, K. J. Am. Chem. Soc. 1993, 115, 6883-6892. (d) Siegbahn, P. E. M.; Crabtree, R. H. J. Am. Chem. Soc. 1996, 118, 4442-4450. (e) 
Su, M.-D.; Chu, S.-Y. Organometallics 1997, 16, 1621-1627. (f) Zaric, S.; Hall, M. B. J. Phys. Chem. A 1998, 102, 1963-1964.

(3) Yang, H.; Kotz, K. T.; Asplund, M. C.; Wilkens, M. J.; Harris, C. B. Acc. Chem. Res. 1999, 32, 551-560.

(4) Arndtsen, B. A.; Bergman, R. G.; Mobley, T. A.; Peterson, T. H. Acc. Chem. Res. 1995, 28, 154-162.

(5) Shilov, A.; Shul'pin, G. B. Chem. Rev. 1997, 97, 2879-2932.

(6) Tran, E.; Legzdins, P. J. Am. Chem. Soc. 1997, 119, 5071-5072.

(7) Debad, J. D.; Legzdins, P.; Lumb, S. A.; Rettig, S. J.; Batchelor, R. J.; Einstein, F. W. B. Organometallics 1999, 18, 3414-3428.

(8) Legzdins, P.; Rettig, S. J.; Veltheer, J. E.; Batchelor, R. J.; Einstein, F. W. B. Organometallics 1993, 12, 3575-3585.

(9) Legzdins, P.; Veltheer, J. E.; Young, M. A.; Batchelor, R. J.; Einstein, F. W. B. Organometallics 1995, 14, 407-417.

(10) Tran, E. T.; Legzdins, P. unpublished results.

(11) For further examples of intermolecular $\mathrm{C}-\mathrm{H}$ bond activation by neopentylidene species, ${ }^{\mathrm{a}-\mathrm{c}}$ and alkane $\mathrm{C}-\mathrm{H}$ bond activation by tungsten complexes, ${ }^{\mathrm{d}-\mathrm{e}}$ see: (a) van der Heijden, H.; Hessen, B. J. Chem. Soc., Chem. Commun. 1995, 145-146. (b) Reference 27. (c) Cheon, J.; Rogers, D. M.; Girolami, G. S. J. Am. Chem. Soc. 1997, 119, 6804-6813. (d) Waltz, K. M.; Hartwig, J. F. Science 1997, 277, 211-213. (e) Schafer, D. F., II; Wolczanski, P. T. J. Am. Chem. Soc. 1998, 120, 4881-4882.

(12) Churchill, D.; Shin, J. H.; Hascall, T.; Hahn, J. M.; Bridgewater, B. M.; Parkin, G. Organometallics 1999, 18, 2403-2406.

(13) Schilling, B. E. R.; Hoffmann, R.; Faller, J. W. J. Am. Chem. Soc. 1979, 101, 592598.

(14) Legzdins, P.; Rettig, S. J.; Sánchez, L.; Bursten, B. E.; Gatter, M. G. J. Am. Chem. Soc. 1985, 107, 1411-1413. 
(15) Bursten, B. E.; Cayton, R. H. Organometallics 1987, 6, 2004-2005.

(16) Ashby, M. T.; Enemark, J. H. J. Am. Chem. Soc. 1986, 108, 730.

(17) For a review of the LX ligand classification system, see: Green, M. L. H. J. Organomet. Chem. 1995, 500, 127-148.

(18) Legzdins, P.; Veltheer, J. E. Acc. Chem. Res. 1993, 26, 41-48.

(19) (a) Herrmann, W. A.; Hubbard, J. L.; Bernal, I.; Forp, J. D.; Haymore, B. L.; Hillhouse, G. L. Inorg. Chem. 1984, 23, 2978-2983. (b) Reference 16. (c) Hubbard, J. L.; McVicar, W. K. Inorg. Chem. 1992, 31, 910-913. (d) Legzdins, P.; Ross, K. J.; Sayers, S. F.; Rettig, S. J. Organometallics 1997, 16, 190-196. (e) Legzdins, P.; Sayers, S. F. Chem. Eur. J. 1997, 3, 1579-1587. (f) Jandciu, E. W.; Kuzelka, J.; Legzdings, P.; Rettig, S. J.; Smith, K. M. Organometallics 1999, 18, 1994-2004.

(20) Kubácek, P.; Hoffmann, R. J. Am. Chem. Soc. 1981, 103, 4320-4332.

(21) Kubácek, P.; Hoffmann, R.; Havlas, Z. Organometallics 1982, 1, 180-188.

(22) Johnson, T. J.; Folting, K.; Streib, W. E.; Martin, J. D.; Huffman, J. C.; Jackson, S. A.; Eisenstein, O.; Caulton, K. G. Inorg. Chem. 1995, 34, 488-499.

(23) Ward, T. R.; Schafer, O.; Daul, C.; Hofmann, P. Organometallics 1997, 16, $3207-$ 3215.

(24) Smith, K. M.; Poli, R.; Legzdins, P. Chem. Eur. J. 1999, 5, 1598-1608.

(25) Costuas, K.; Saillard, J.-Y. Organometallics 1999, 18, 2505-2512.

(26) Legzdins, P.; Rettig, S. J.; Sánchez, L. Organometallics 1988, 7, 2394-2403.

(27) Coles, M. P.; Gibson, V. C.; Clegg, W.; Elsegood, M. R. J.; Porrelli, P. A. J. Chem. Soc., Chem. Commun. 1996, 1963-1964.

(28) Warren, T. H.; Schrock, R. R.; Davis, W. M. J. Organometal. Chem. 1998, 569, 125-137.

(29) Debad, J. D.; Legzdins, P.; Rettig, S. J.; Veltheer, J. E. Organometallics 1993, 12, 2714-2725. 
(30) Brunet, N.; Debad, J. D.; Legzdins, P.; Trotter, J.; Veltheer, J. E.; Yee, V. C. Organometallics 1993, 12, 4572-4579.

(31) Hall, C.; Perutz, R. N. Chem. Rev. 1996, 96, 3125-3146.

(32) For recent kinetic, spectroscopic, and theoretical investigations implicating transition metal alkane complexes, see: (a) Bromberg, S. E.; Yang, H.; Asplund, M. C.; Lian, T.; McNamara, B. K.; Kotz, K. T.; Yeston, J. S.; Wilkens, M.; Frei, H.; Bergman, R. G.; Harris, C. B. Science 1997, 278, 260-263. (b) Green, J. C.; Jardine, C. N. J. Chem. Soc., Dalton Trans. 1998, 1057-1061. (c) Geftakis, S.; Ball, G. E. J. Am. Chem. Soc. 1998, 120, 9953-9954. (d) Wick, D. D.; Reynolds, K. A.; Jones, W. D. J. Am. Chem. Soc. 1999, 121, 3974-3983. (e) Martin, R. L. J. Am. Chem. Soc. 1999, 121, 9459-9460.

(33) Benson, M. T.; Cundari, T. R.; Moody, E. W. J. Organomet. Chem. 1995, 504, 113.

(34) Yang, H.; Asplund, M. C.; Kotz, K. T.; Wilkens, M. J.; Frei, H.; Harris, C. B. J. Am. Chem. Soc. 1998, 120, 10154-10165.

(35) Musaev, D. G.; Morokuma, K. J. Am. Chem. Soc. 1995, 117, 799-805.

(36) Caulton, K. G. New J. Chem. 1994, 18, 25-41.

(37) For an alternative interpretation of bond strengths in late metal amido complexes based on bond polarity considerations rather than $\pi$ bonding, see: Holland, P. L.; Andersen, R. A.; Bergman, R. G. Comments Inorg. Chem. 1999, 21, 115-129.

(38) Poli, R. Organometallics 1990, 9, 1892-1900.

(39) For a complete analysis of the $\sigma$-bonding interactions and $z^{2}$ and $x^{2}-y^{2} d$ orbital rehybridization responsible for this pairwise angular distortion of $\mathrm{CpML}_{2} \mathrm{~L}_{2}$ complexes, see: Lin, Z.; Hall, M. B. Organometallics 1993, 12, 19-23.

(40) Legzdins, P.; Rettig, S. J.; Ross, K. R. Organometallics 1993, 12, 2103-2110.

(41) Legzdins, P.; Young, M. A.; Batchelor, R. J.; Einstein, F. W. B. J. Am. Chem. Soc. 1995, 117, 8798-8806. 
(42) Legzdins, P.; Lundmark, P. J.; Phillips, E. C.; Rettig, S. J.; Veltheer, J. E. Organometallics 1992, 11, 2991-3003.

(43) Scott, A. P.; Radom, L. J. Phys. Chem. 1996, 100, 16502-16513.

(44) Wu, Y.-D.; Peng, Z.-H.; Chan, K. W. K.; Liu, X.; Tuinman, A. A.; Xue, Z. Organometallics 1999, 18, 2081-2090.

(45) James, T. A.; McCleverty, J. A. J. Chem. Soc. (A) 1971, 1596-1601.

(46) Hunter, A. D.; Legzdins, P. Organometallics 1986, 5, 1001-1009.

(47) Christensen, N. J.; Hunter, A. D.; Legzdins, P.; Sánchez, L. Inorg. Chem. 1987, 26, 3344-3347.

(48) Chin, T. T.; Legzdins, P.; Trotter, J.; Yee, V. C. Organometallics 1992, 11, 913922.

(49) Alegre, B.; de Jesus, E.; Vazquez de Miguel, A.; Royo, P.; Lanfredi, A. M. M.; Tiripicchio, A. J. Chem. Soc., Dalton Trans. 1988, 819-825.

(50) For the X-ray crystallographic studies used for comparisons with the $\mathrm{CpM}(\mathrm{NO})\left(\mathrm{CH}_{3}\right)_{2},{ }^{\mathrm{a}, \mathrm{b}} \mathrm{CpM}(\mathrm{NO})\left(\mathrm{CH}_{2}\right)\left(\mathrm{NH}_{3}\right),{ }^{\mathrm{a}, \mathrm{c}} \mathrm{CpM}(\mathrm{NO})\left(\mathrm{CH}_{3}\right)\left(\mathrm{NH}_{2}\right),{ }^{\mathrm{d}, \mathrm{e}}$ and trans ${ }_{-}^{\mathrm{f}, \mathrm{g}}$ and cis-CpM(NO) $\left(\mathrm{CH}_{3}\right)_{2}\left(\mathrm{NH}_{3}\right)^{\mathrm{h}, \mathrm{i}}$ complexes of Mo and W, see: (a) Reference 8. (b) Reference 26. (c) Reference 10. (d) Reference 9. (e) Reference 19d. (f) Reference 40. (g) Debad, J. D.; Legzdins, P.; Lumb, S. A.; Batchelor, R. J.; Einstein, F. W. B. Organometallics 1995, 14, 2543-2555. (h) Reference 49. (i) Reference 30.

(51) Stowasser, R.; Hoffmann, R. J. Am. Chem. Soc. 1999, 121, 3414-3420.

(52) Bengali, A. A.; Bergman, R. G.; Moore, C. B. J. Am. Chem. Soc. 1995, 117, 38793880.

(53) Siegbahn, P. E. M. J. Am. Chem. Soc. 1996, 118, 1487-1496.

(54) Poli, R. Chem. Rev. 1996, 96, 2135-2204.

(55) Poli, R. Acc. Chem. Res. 1997, 30, 494-501.

(56) (a) Cacelli, I.; Keogh, D. W.; Poli, R.; Rizzo, A. J. Phys. Chem. A 1997, 101, 98019812. (b) Poli, R.; Quadrelli, E. A. New J. Chem. 1998, 22, 435-450. (c) Collange, 
E.; Duret, D.; Poli, R. J. Chem. Soc., Dalton Trans. 1999, 875-880. (d) Poli, R.;

Smith, K. M. Eur. J. Inorg. Chem. 1999, 877-880. (e) Poli, R.; Smith, K. M. Eur. J. Inorg. Chem. 1999, 2343-2346.

(57) Legzdins, P.; McNeil, W. S.; Smith, K. M.; Poli, R. Organometallics 1998, 17, 615-622.

(58) Smith, K. M.; Poli, R.; Legzdins, P. Chem. Commun. 1998, 1903-1904.

(59) (a) Su, M.-D.; Chu, S.-Y. J. Am. Chem. Soc. 1997, 119, 5373-5383. (b) Su, M.-D.;

Chu, S.-Y. Inorg. Chem. 1998, 37, 3400-3406. (c) Su, M.-D.; Chu, S.-Y. Chem.

Eur. J. 1999, 5, 198-207.

(60) Tomàs, J.; Lledós, A.; Jean, Y. Organometallics 1998, 17, 4932-4939.

(61) Niu, S.; Hall, M. B. J. Am. Chem. Soc. 1999, 121, 3992-3999.

(62) Frisch, M. J.; Trucks, G. W.; Schlegel, H. B.; Gill, P. M. W.; Johnson, B. G.; Robb, M. A.; Cheeseman, J. R.; Keith, T. A.; Petersson, G. A.; Montgomery, J. A.;

Raghavachari, K.; Al-Laham, M. A.; Zakrzewski, V. G.; Ortiz, J. V.; Foresman, J. B.; Cioslowski, J.; Stefanov, B. B.; Nanayakkara, A.; Challacombe, M.; Peng, C. Y.; Ayala, P. Y.; Chen, W.; Wong, M. W.; Andres, J. L.; Replogle, E. S.; Gomperts, R.; Martin, R. L.; Fox, D. J.; Binkley, J. S.; Defrees, D. J.; Baker, J.; Stewart, J. P.; Head-Gordon, M.; Gonzales, C.; Pople, J. A. Gaussian 94 (Revision E.1); Gaussian Inc.: Pittsburgh, PA, 1995.

(63) Becke, A. D. J. Chem. Phys. 1993, 98, 5648-5652.

(64) Dunning, T. H., Jr.; Hay, P. J. In Modern Theoretical Chemistry; H. F. Schaefer, III, Ed.; Plenum Press: New York, 1976; pp 1-28.

(65) Hay, P. J.; Wadt, W. R. J. Chem. Phys. 1985, 82, 270-283.

(66) Wadt, W. R.; Hay, P. J. J. Chem. Phys. 1985, 82, 284-298.

(67) Hay, P. J.; Wadt, W. R. J. Chem. Phys. 1985, 82, 299-310.

(68) Schaftenaar, G. Molden v3.2; CAOS/CAMM Center Nijmegen, Toernooiveld: Nijmegen, The Netherlands, 1991. 